\title{
The Role of Immune Response and the Impact of Biological Drugs in Psoriasis Patients
}

\author{
Amedeo Amedei and Mario Milco D'Elios \\ University of Florence \\ Italy
}

\section{Introduction}

Psoriasis is a chronic immune-mediated skin disease with a intricate pathogenesis and a strong genetic background (Nickoloff et al., 2007a), that affects approximately 1-3\% of the worldwide population, with an equal sex distribution (Stern et al., 2004). The main type of psoriasis is chronic plaque psoriasis (Cpp) accounting for approximately 85-90\% of all cases. The Cpp is characterized by erythematous scaly plaques, usually on elbows, knees, scalp and buttocks. Plaque size can diverge from minimal to the involvement of the entire skin surface (erythrodermic psoriasis) (C. E. Griffiths et al., 2007; Nestle et al., 2009). Other forms of psoriasis comprise guttate psoriasis, inverse, palmoplantar and generalized pustular psoriasis (C. E. Griffiths \& Barker, 2007; Nestle et al., 2009).

The concept of psoriasis as "the disease of healthy people" has long been surpassed, nowadays we know that during the time course of this disease, as a consequence of dysregulated immunity and ensuing inflammation, certain conditions may appear at somewhat unpredictable time points in a progressive fashion; these so-called comorbidities, although targeting different organs, share common pathogenetic factors. They often become manifest years after the onset of skin manifestations and are often observed in severe forms of psoriasis.

Psoriatic Arthritis (PsA) is traditionally included among common co-morbidities, even if it should be rather considered a component of the clinical spectrum of psoriatic disease. PsA involves peripheral joints, the axial skeleton, sacroiliac joints, nails and enthuses, and is frequently associated with psoriatic skin lesions. The prevalence of PsA ranges from 5 to $40 \%$ among psoriatic patients lesions (D. D. Gladman, 2009; Nograles et al., 2009).

Recently, co-morbidities like cardiovascular disease, obesity and metabolic syndrome have been found to be associated with psoriasis, raising the idea that psoriasis might not be only a skin disorder (Gerdes \& Mrowietz, 2009; Kimball et al., 2008a; Menter et al., 2008).

Psoriasis patients suffer also from considerable psychological and financial burdens resulting in a significantly impaired quality of life (Rapp, et al., 1999); likewise traditional systemic psoriasis therapies (methotrexate [MTX], cyclosporin A, retinoids or PUVA therapy) have a potential for long-term toxicity and cannot always provide plenty disease improvement (Pathirana et al., 2009; Smith et al., 2009). Thus, the development of agents efficiently targeting key steps in the pathogenesis of psoriasis and co-morbidities is clearly an important goal. 


\section{Pathogenesis}

Psoriasis is thought to be a complex condition resultant by a combination of genetic and environmental factors. The acute forms of psoriasis, guttate and generalized pustular psoriasis (von Zumbusch psoriasis), are both associated with infections (typically bhaemolytic streptococcal or a viral infection). Other triggering factors which may elicit psoriasis in predisposed individuals include trauma (Koebner phenomen) (Eyre \& G. G. Krueger, 1984), HIV infection (Reveille et al., 1990), psychogenic stress (Gupta et al., 1989) and definite drugs (e.g. lithium, beta-blockers, interferons and high dose corticosteroids) (Abel et al., 1986).

Histological examination of psoriatic plaques reveals hyperproliferation of keratinocytes (Kcs) with parakeratosis, increased angiogenesis and dermal infiltration of immune cells, predominantly $\mathrm{T}$ cells, neutrophils, macrophages and dendritic cells (DCs) (Figure 1) (Nestle et al., 2009; Nickoloff et al. 2007b).

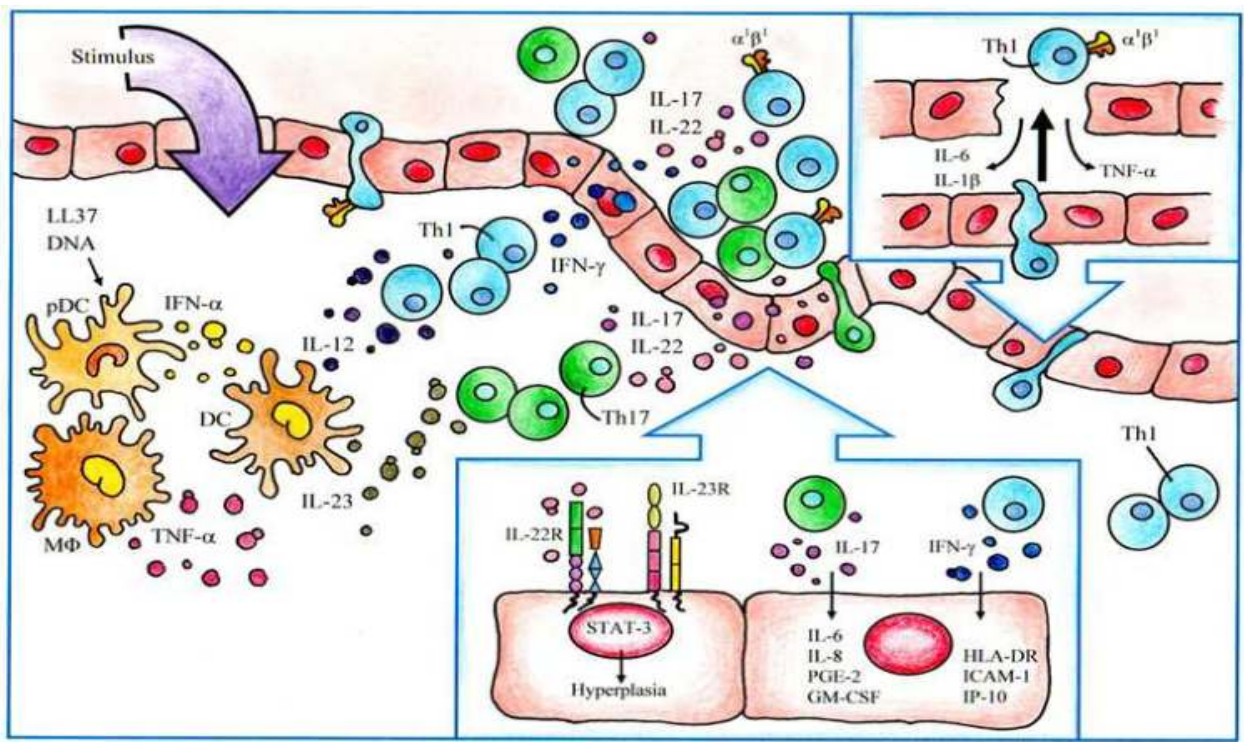

Fig. 1. Psoriatic skin lesions evolution. Different stimuli (e.g. infections, etc.) can trigger an initial episode of psoriasis in genetically predisposed individuals. After starting, the earliest events driving the inflammatory eruption are the secretion of INF- $\alpha$ from pDCs (plasmacytoid dendritic cells) and the production of TNF- $\alpha$ by immune cells of both innate and adaptive response. Large amounts of IFN- $\alpha$ induce activation of the local immune effector cells that secrete pro-inflammatory cytokines. TNF- $\alpha$ is a very active cytokine of the inflammatory infiltrate and is principally secreted by activated macrophages $(M \Phi)$, dermal DCs, keratinocytes and T cells. The elevated levels of TNF- $\alpha$ lead to the maturation of DCs into forceful APCs (antigen presenting cells) and, with other cytokines, up-regulates the expression of endothelial E-selectin and ICAM-1 attracting further CLA+ T cells in the skin. Also, the panel of cytokines released by $\mathrm{T}$ cells contributes to the stimulation of epidermal keratinocytes and is at least, in some measure, responsible for typical psoriasis skin changes. They induce the expression of ICAM-1, CD40 and MHC-II and trigger keratinocyte hyper-proliferation. 
The increased dermis vascularity is driven by angiogenic factors, such as VEGF (vascular endothelial growth factor ), highly present in psoriasis plaques (Detmar et al., 1994). Also, the interaction between VEGF and the angiopoietin/Tie signaling pathway is modulated by TNF-a (Tumour necrosis factor-a), that together with interleukin 12 (IL-12) and IL-23 are well known to be crucial immunological mediators in psoriasis. (Holash et al., 1999; Kuroda et al., 2001). Whereas IL-12 induces Th1 (T helper 1) differentiation and thus increases the production of TNF-a, IL-23 stimulates primarily Th17 cells, which secrete most importantly pro-inflammatory cytokines such as IL-17 and IL-22 (Nestle et al., 2009; Toichi et al., 2006; Torti \& Feldman, 2007).

Increased concentrations of TNF-a and IL-12/IL-23 have been found as in psoriatic skin (Nestle et al., 2009) as in the synovial fluid and tissue of patients with PsA (FitzGerald \& Winchester , 2009; Ritchlin et al, 1998). Their role in psoriasis genesis is highlighted by the successful treatment of psoriasis by agents blocking these cytokines (Boker et al., 2007; Mössner et al., 2008; Scalon et al., 2009). In addition, polymorphisms of IL-23 receptor gene and gene encoding the shared p40 subunit of IL-12 and IL-23 have been linked to psoriasis development (Elder et al., 2010; Hüffmaier et al., 2009; Nestle et al., 2009).

\section{Genetics of psoriasis}

Family studies have shown that psoriasis has a strong genetic component although the inheritance pattern is still unclear. $71 \%$ of patients with childhood psoriasis have a positive family history (Morris et al., 2001) and analysis of concordance rates in twin studies show a threefold increased risk of psoriasis in monozygotic twins compared to dizygotic twins (Brandrup et al., 1978; Pisani \& Ruocco, 1984).

At least ten chromosomal loci have been identified showing statistically significant evidence for linkage to psoriasis (PSORS 1-10). However, the only region that has consistently been identified in genetic screens of families with psoriasis is the major-histocompatibility complex (MHC) region on chromosome 6 named PSORS1 (Capon et al., 2008; Nair et al., 2006), that is responsible for up to $50 \%$ of genetic susceptibility to psoriasis. Within PSORS1 the human leukocyte antigen-C (HLA-C) gene which is the strongest candidate gene for psoriasis, precisely its allele HLACw6 (HLA-Cw*0602) the predominant risk allele (Nair et al., 2006): individuals with this allele have a 10-20-fold increased risk of developing psoriasis (Mallon et al., 1999).

HLA-Cw6 positive and negative psoriasis patients may exhibit distinctive clinical phenotypes (Henseler \& Christophers, 1985): guttate psoriasis is mostly confined to HLA$\mathrm{Cw}^{+}$patients meanwhile psoriatic nail disease, palmoplantar pustulosis and psoriatic arthritis are more common in HLA-Cw6- patients (Fan et al., 2007; Gudjonsson et al., 2006). Furthermore, partial or total remission during pregnancy is much more frequent in HLA$\mathrm{Cw}^{*} 0602{ }^{+}$women (Gudjonsson et al., 2006).

Despite this strong association, the functional role of HLA-Cw6 remains unknown; as far as we know HLACw6 may exert its effect through the specific or the innate immune system (Figure 2): HLA-Cw6 may act via the adaptive immune system by its antigen presenting capacity and the fact that guttate psoriasis (sturdily associated with HLA-Cw6) is triggered by streptococcal pharyngitis (J. C. Prinz, 2001), supports this hypothesis. HLA-Cw6 may also exert an innate immune response via its interaction with KIRs (killer immunoglobulin- 
like receptors) of natural killer (NK) and natural killer T (NKT) cells, which are implicated, in psoriasis pathogenesis (Nickoloff, 1999a). KIRs recognize different types of HLA-C molecules leading to either an overall activating or inhibitory immune response. KIRs have been associated with psoriasis and PsA (Martin et al., 2002). HLA-Cw6 is a natural ligand for KIR2DL1 (an inhibitory receptor) and it is possible that interaction between HLA-Cw6 and PaKIR2DL1 would lead to aberrant function of lymphoid cells in psoriasis pathogenesis.

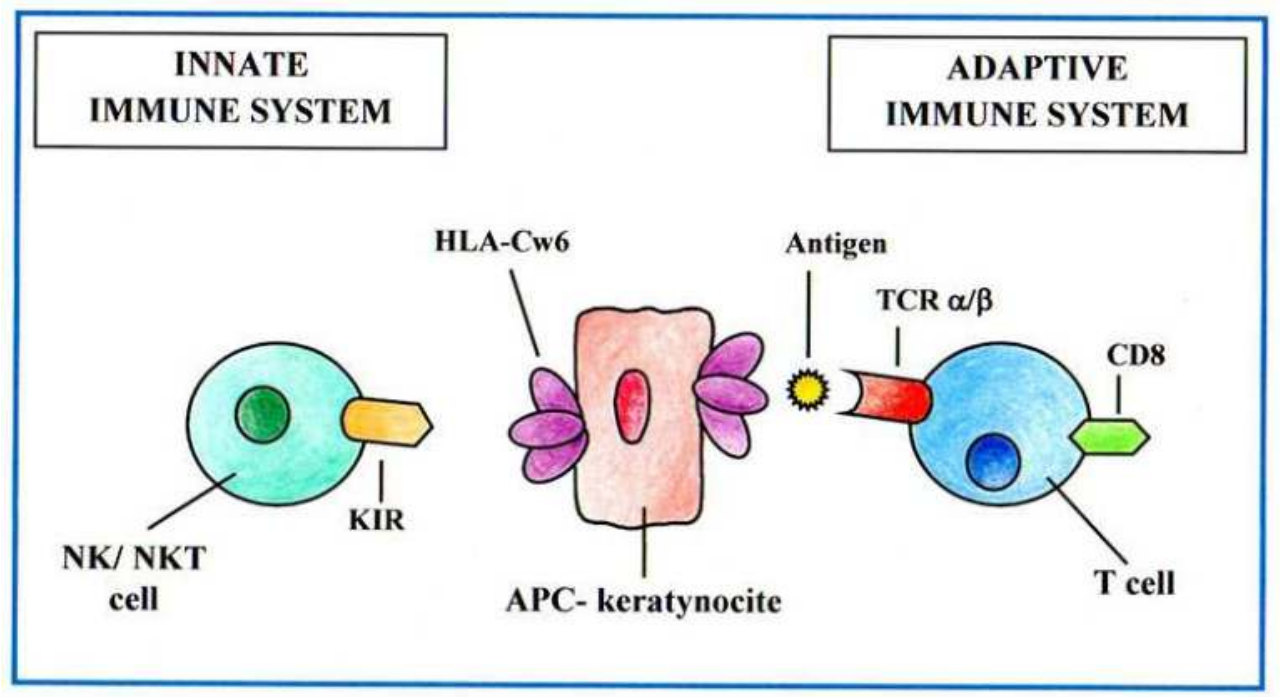

Fig. 2. Hypothetical regulating role of HLA-Cw6 in both specific and innate immune responses.

HLA-Cw6 expressed on APCs can trigger specific immune responses by presentation of processed antigen to the TCR of CD8+ T cells. Also, innate immune response can be elicited by interaction of HLA-Cw6 with its natural Killer immunoglobulin-like receptors expressed on NK and NKT cells.

A new psoriasis susceptibility gene ZNF313/RNF114, which may regulate T cell activation through ubiquitin ligase activity, has been identified (Capon et al., 2008). All these data further supports the concept that multiple gene products share a role in the immune regulation of psoriasis, contributing to disease pathogenesis.

\section{Immune response}

Although the initial event triggering a psoriatic lesion is still unknown many factors have been shown to play a role in the pathogenesis of psoriasis: physical trauma, infections, stress, drugs, alcohol and smoking can all trigger an initial episode of psoriasis in individuals with genetic predisposition (Bowcock \& J. G. Krueger, 2005).

This initial trigger activates dendritic cells, favoring their migration to skin-draining lymph nodes, where antigen-specific T cells (primed by DCs) differentiate into effector $\mathrm{T}$ cells, 
which then traffic to the skin where they induce - in concert with other cells, especially dermal DCs - the creation of a primary psoriatic plaque. During this step some T cells and DCs start to infiltrate the epidermis, where stimulating KCs support the typical epidermal changes (Bowcock \& J. G. Krueger, 2005).

Epidermal keratinocytes are able to recruit and activate $\mathrm{T}$ cells and most $\mathrm{T}$ cells infiltrating psoriatic skin are divided into Th1 $\left(\mathrm{CD}^{+}\right)$and T cytotoxic $1\left(\mathrm{Tc} 1 ; \mathrm{CD} 8^{+}\right)$subsets (J. G. Krueger, 2002). Two further $T$ cell subtypes, Th17 cells (McKenzie et al., 2006) and regulatory $\mathrm{T}$ cells (Treg) (Sugiyama et al, 2005) have been identified as important contributors to the pathogenesis of autoimmune diseases such as psoriasis (Figure 3).

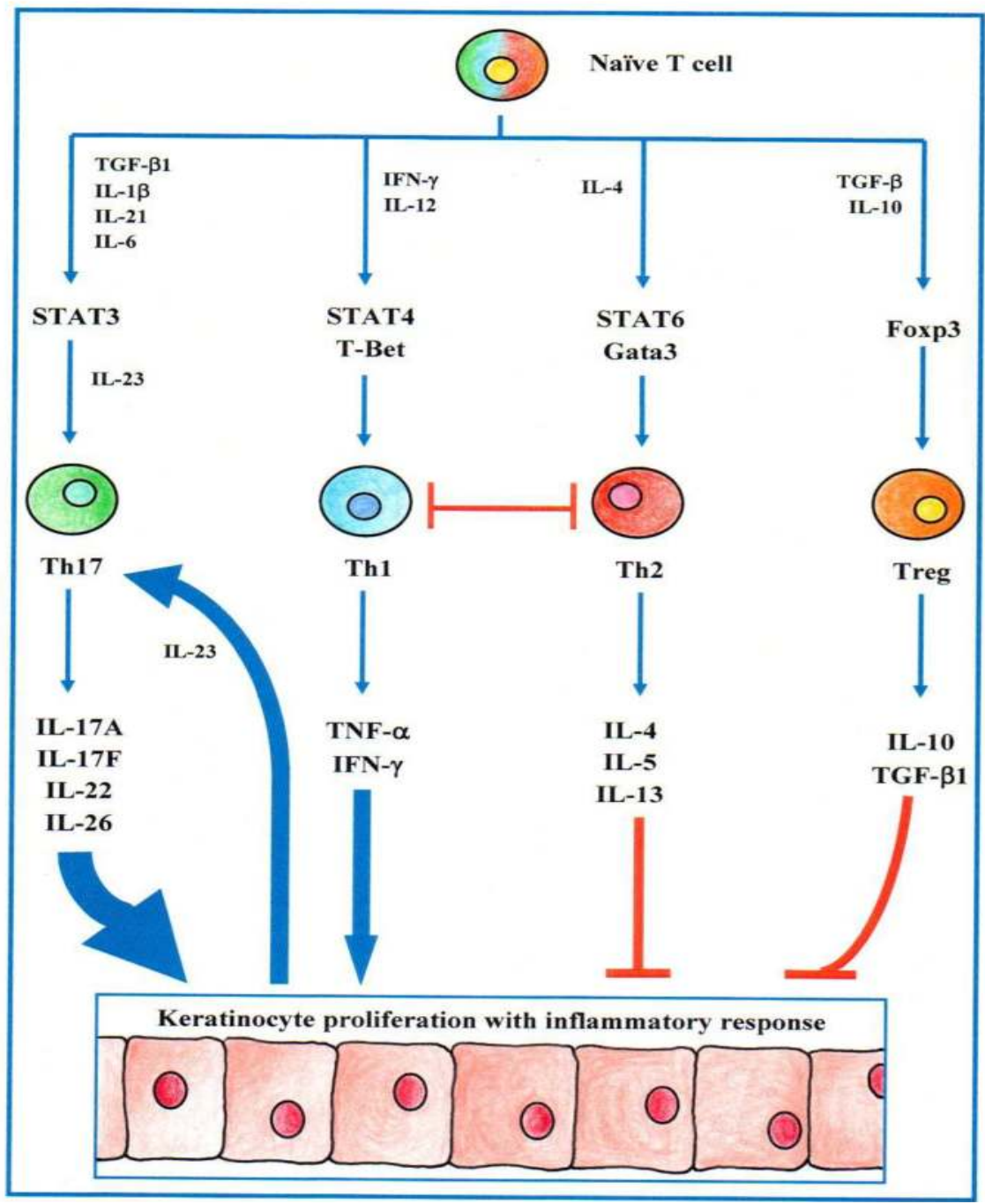

Fig. 3. Role of CD4 T cell subtypes in psoriasis. 
Th1 and Th17 pro-inflammatory cytokines mediate keratinocyte hyperproliferation and trigger a 'vicious cycle' of inflammation. IL-23 secreted principally by keratinocytes, dendritic cells and macrophages is critical for maintenance of Th17 function. Low levels of anti-inflammatory cytokines released by Th2 and Tregs potentially counteract but cannot balance the effects of Th1/Th17 cytokines.

From the foregoing it is clear that the contribution of both innate and adaptive immune responses are important in mediating the inflammatory psoriasis cascade (Gaspari, 2006) (Figure 1).

\subsection{Aberrant activation of the innate fraction of the skin immune system}

The present knowledge of the possible role of innate immunity cells (Kcs, Dcs, neutrophils, macrophages, NK and NKT cells) in psoriasis will be discussed.

\subsubsection{Keratinocytes in psoriasis}

Over the last 20 years it has been regularly discussed if psoriatic skin lesions arise from a primary alteration in epidermal keratinocytes or in T cells (Figure 1); the current view is that infiltrating $\mathrm{T}$ cells initiate and maintain psoriasis. In this vision, cytokines (e.g., IL-1, IL-6 and IFN- $\gamma$ ) secreted by $\mathrm{T}$ cells and other inflammatory cells (DCs, macrophages and neutrophils) would trigger KCs hyperproliferation, inducing epidermal hyperplasia (J. G. Krueger, 2002). In particular, IL-23, whose expression is increased in psoriatic lesion (Piskin et al., 2006), has been implied in the development of epidermal acanthosis, most likely through the induction of IL-22 (Zheng et al., 2007); injection of IL-23 into mouse dermis induces as dermal inflammation as epidermal hyperplasia similarly to features seen in psoriasis (J. R. Chan et al., 2006).

Previous studies (J. G. Krueger, 2002) suggested an additional explanation for the chronic epidermal hyperplasia in psoriatic lesions: the migration of $\mathrm{T}$ cells in the epidermis would firstly break the basement membrane, which has been shown to have large areas with reduced staining intensity for collagen IV and laminins (Fleischmajer et al., 2000), and secondly disrupt desmosome connection between KCs. These two events could be interpreted by $\mathrm{KCs}$ as an injury and therefore induce a wound repair response. As a consequence many mitogenic cytokines would be released by KCs triggering a regenerative epidermal growth. Hence, T cells in psoriatic epidermis would be responsible for the chronic hyperplasia as by releasing pro-inflammatory cytokines as by disrupting epidermal integrity.

Another evidence against the fundamental role of $\mathrm{T}$ cells in psoriasis arise from the observation that $\mathrm{HIV}^{+}$patients (which usually have reduced number of $\mathrm{CD}^{+} \mathrm{T}$ cells) develop psoriasis with similar frequency as the rest of the population (Namazi, 2004).

Finally, in 2005 Zenz et al. reported an interesting animal model with psoriasis-like features (Zenz et al., 2005); They knocked out JunB and c-Jun, two components of the AP-1 transcription factor, which control cell proliferation and differentiation, cytokine production, and stress responses in the skin. The importance of this animal model lies in the fact that JunB is located in the PSORS6 locus, which has been shown to be a psoriasis susceptibility region (Hensen et al., 2003). Interestingly, these mice developed not only 
inflammatory skin lesions but also a form of destructive arthritis. This evidence suggested that alteration in the epidermal Jun-pathway may be sufficient to induce inflammatory reactions in the skin as well as in the joints. At the skin level these mice showed typical hallmarks of psoriasis: hyperkeratosis, enlarged blood vessels, infiltration of $\mathrm{T}$ cells and neutrophils, and up-regulation of pro-inflammatory cytokines.

The most intriguing aspect was the examination of the $\mathrm{T}$ cells role in development of psoriasis in a genetic model: upon deletion of JunB and c-Jun proteins in Rag2-deficient mice (mice deficient of T/B cells), skin changes like in psoriasis were still induced, though they were milder. These data suggest a minor role for $\mathrm{T}$ cells in the etiology of psoriasis-form skin inflammation, and that primary alterations in KCs were sufficient to drive psoriasisform changes in the mice skin. But before stating that KCs instigate psoriasis in humans, the relevance of this model must be discussed further. A recent study (Haider et al., 2006) showed that the JunBwas expression increased in psoriatic plaques instead of decreased/deleted as in the Zenz mouse model, suggesting a role for JunB as a transcriptional activator of disease-related genes in psoriatic KCs.

The ongoing discussion about the primary instigator of psoriasis reflects the complexity of this disease and the still elusive interplay between KCs and immune cells in driving psoriasis.

This problem was further addressed in a another mouse model, in which STAT-3 was constitutively activated in basal KCs under the control of the keratin 5 promoter (K5.Stat3C) (Sano et al., 2005). As in human psoriatic plaques, induced lesions of K5.Stat3C mice shown a considerable number of $\mathrm{CD}^{+} \mathrm{T}$ and $\mathrm{CD}^{+} \mathrm{T}$ cells in the epidermis. For psoriasis development, this model required both activated STAT-3 in KCs and activated T cells in the dermis and epidermis of the transgenic rodents, suggesting the theory that KCs and T cells could act together in psoriasis pathogenesis.

\subsubsection{Neutrophilic granulocytes}

Early studies in psoriasis (Jablonska, 1986), in which the initial (pre-pinpoint) lesions were studied histologically,indicated that the primary abnormality in a developing lesion of psoriasis is the perivascular accumulation of neutrophils as well as their epidermis invasion (Kogoj phenomenon). Next, these neutrophils accumulations lead to microscopically detectable microabscesses (Munro abscesses). In many patients with psoriasis, these micropustules may enlarge and become clinically visible as sterile 2-3-mm pustules. In some patients, pustules are the primary visible abnormality, often on an erythematous base.

The presence of neutrophils must be important for the formation of psoriatic skin lesions, in fact agranulocytosis has been reported to result in the remission of psoriasis (Toichi et al., 2000). Next, neutrophils can contribute to the hyperproliferation of keratinocytes by the effects of human leucocyte-derived elastase (Rogalski et al., 2002).

\subsubsection{Natural killer T cells}

The potential role of cells expressing NK receptors in psoriatic skin was firstly proposed by Nickoloff (Nickoloff et al., 1999b); in further experiments, he showed that a CD94+/CD161+ NKT cell line (isolated from a psoriatic patient) injected in prepsoriatic skin of a SCID 
mouse, gave rise to creation of psoriatic plaque characterized by diffuse keratinocyte expression of CD1d, CD161 ${ }^{+} \mathrm{T}$ cells infiltration and marked presence of mRNA for IFN-c and IL-15 (Nickoloff et al., 2000).

In line with these data, it seems that constitutive CD1d expression on prepsoriatic skin keratinocytes represents a primary prerequisite that ensures their contact with the CD161 molecule on NKT cells. This interaction might also represent one of the critical events in the triggering of psoriasis as CD1d-bearing keratinocytes can present endogenous (self) or exogenous (bacterial, viral) glycolipids to NKT-cells. Consequently to the recognition of glycolipid antigens, NKT cells produce large amounts of IFN-c which induces stronger keratinocyte expression of CD1d; in this way the pathogenic mechanism of psoriatic plaques is not only initiated but also maintained.

Numerous studies have addressed the issue of NKT cells in the lesional skin of psoriasis patients and a constant result evidenced by independent groups of investigators is that $\mathrm{CD}_{161^{+}} \mathrm{T}$ cells appear in greater numbers in lesional skin of patients with psoriasis than in normal healthy skin and/or prepsoriatic skin (Bonish et al., 2000; Cameron et al., 2002; Curry et al., 2003; Vissers et al., 2004a).

However, Curry group shown a greater frequency of CD161+ $\mathrm{T}$ cells yet in the prepsoriatic skin in comparison with the normal skin, suggesting that certain immune response dysregulations exists in the uninvolved skin and creates a milieu, promoting the psoriatic lesions onset (Curry et al., 2003).

A flow cytometric analysis of psoriatic tissue-infiltrating $\mathrm{T}$ cell demonstrated the presence of $\mathrm{CD}^{+}$cells expressing also CD16, CD56, CD158b, CD94 or NKG2A and CD4-CD8-, the majority of these is a subset of NKT cells (Liao et al., 2006). In addiction a recent study (Zhao et al., 2008) confirmed that NKT cells as well as CD1d molecules were increased within psoriatic skin.

The supposed pathogenic role of NKT cells in psoriasis is also supported by the effects of different pharmacological treatments, that decreases NKT cell numbers in psoriatic plaques, in particular the clinical efficacy of betamethasone dipropionate (Bovenschen et al., 2007; Vissers et al., 2004b, 2008;) and similarly of alefacept that induce an improvement in plaque severity accompanied by significant reductions of dermal CD94 ${ }^{+}$and $\mathrm{CD} 161^{+}$(Bovenschen et al., 2007).

In general, these data strongly indicate that lesional CD94 ${ }^{+}$and CD161+ NKT cells actively participate in the development and/or maintenance of psoriatic lesions, but the relative relevance of each of these subsets remains elusive. However, it might be hypothesized that epidermal NKT cells play a major pathogenic role due to their direct interaction with CD1d ${ }^{+}$ keratinocytes and the resulting hyperproliferation while the dermal component of NKT cells participates in the immune response through the interaction with CD1d-bearing dermal dendritic cells and monocytes.

Likewise other Th1-mediated autoimmune diseases, psoriasis is associated with decreased numbers of circulating NKT cells (Cameron et al., 2003; Koreck et al., 2002; van der Vliet et al., 2001;); Koreck reported that decreased percentage of NKT cells population in blood of psoriasis patients tended to be even lower in those with frequently relapsing (Koreck et al., 2002). Moreover, different systemic therapy regimens resulted in the recovery of these cells, 
but their percentage remained significantly lower in comparison with healthy control subjects. In contrast, Langewouters group showed that the number of circulating CD94+ an CD161 ${ }^{+}$cells was significantly higher in patients with moderate-to-severe as compared to patients with mild psoriasis (Langewouters et al., 2008). It has been also reported that circulating CD161 ${ }^{+}$NKT cells in people with severe psoriasis belong to Th1 cells (W. L. Chan et al., 2003) and that treatment with alefacept or efalizumab causes significant reduction in their number (Larsen et al., 2007; van Lingen et al., 2008). These observations imply that distinct subsets of NKT cells differentially regulate immune responses and that their relative imbalance might be of importance in the psoriasis pathogenesis, but the precise impact of these findings remains unclear.

\subsubsection{Accessory cells (Dendritic cells and macrophages)}

DCs are involved in the development of tolerance (Steinman et al., 2003) and are the unique professional antigen-presenting able to take up antigen in the tissue they reside in and to migrate to the draining lymph nodes; here activate naive $\mathrm{T}$ cells, generating specific $\mathrm{T}$-cell responses (Teunissen, 2005).

In the peripheral tissues DCs receive all kinds of microenvironment signals, that influence the their maturation process, determining the phenotype and function of mature DCs and their type 1 /type 2 polarizing potential. In case of risk (e.g. infection, cancer), DCs will transform into strong stimulatory antigen presenting cells, whereas under non pathological steady-state conditions DCs do not reach full maturation and they will present self-peptides MHC complexes in the presence of insufficient costimulatory molecules, inducing T-cell anergy or expansion of regulatory $\mathrm{T}$ cells (peripheral tolerance). If this delicate balance of immune reactivity vs. tolerance is broken, chronic inflammatory diseases, like psoriasis, may develop.

In the absence of pathogenic substances, stress signals from neighbouring cells (e.g. necrotic cells) can activate DCs enabling them to stimulate naive T cells (Gallucci et al., 1999). In relation to this, Krueger has expressed an remarkable view concerning traumatic injuries (breaches in the basement membrane and disruption of desmosome connections between adjacent keratinocytes) caused by migrating $\mathrm{T}$ cells and DCs in the epidermis, that are possibly involved in the development of psoriasis lesions (J. G. Krueger, 2002). Keratinocytes will respond to these defects by overproduction of cytokines, among others TNF-a, a key cytokine to induce DC migration/maturation.

Another exciting point to mention is the observation that DC development is also affected by mutual interaction with NKT cells (Taniguchi et al., 2003): weak responses by NKT cells to glycolipid /CD1d complexes can be enhanced by DC-derived IL-12, resulting in upexpression of IFN-c by NK T cells. This interaction may be relevant in psoriasis.

DCs are numerous in the dermal part of psoriasis skin and many of them exhibit an activated phenotype $\left(\mathrm{CD}^{+}{ }^{+}, \mathrm{CD}^{+} 3^{+}, \mathrm{CD}^{+} 6^{+}\right.$and DC-LAMP $)$(Abrams et al., 2000; Teunissen, 2005) and may be an important source of TNF-a (Nickoloff et al., 1991; Zhou et al., 2003).

Recent evidences from different genetic mouse models show that also the macrophages can contribute to T-cell-mediated and epidermis-mediated psoriasis-form skin inflammation 
and in particular the data from the CD18hypo PL/J psoriasis mouse model demonstrate (Wang et al., 2009) that the psoriasis-form inflammatory skin disorder critically depends on an appropriate activation of macrophages, with ample release of TNF-a.

In human psoriasis, the number of epithelium-lining macrophages was reported to increase in lesional skin. These macrophages can play a role in the regulation of epidermal proliferation and differentiation (van den Oord \& de Wolf-Peeters, 1994); also vigorous interactions between macrophages and keratinocytes (Djemadji-Oudjiel et al., 1996) may be involved in the psoriasis pathogenesis (van den Oord \& de Wolf-Peeters, 1994).

Macrophages, under different conditions, secrete various pro-inflammatory cytokines: TNF$\alpha$, IL-1b, IFN- $\alpha / \beta$, IL-6, IL-10, IL-12, and IL-18, (Willment et al., 2003) and notably, in a recent study $\mathrm{CD}^{+} 8^{+}$macrophages were identified as important TNF- $\alpha$ source in human psoriasis and upon treatment with anti-TNF- $\alpha$ antibody macrophage levels decreased in the plaque psoriasis, with clinical psoriasis resolution (Marble et al., 2007). In according to this finding, it is also showed that $\mathrm{CD}^{+}$macrophages as important TNF- $\alpha$ source in human psoriatic skin, which had distinctly decreased number and TNF- $\alpha$ concentration following bathPUVA therapy (Wang et al., 2009). This was also found in a T-cell-independent mouse model, with an increase of TNF- $\alpha$ in macrophages (Stratis et al., 2006).

Based on literature data, an emerging model of psoriasis pathogenesis in humans suggests that dermal macrophages, activated by T-cell cytokines, produce large amounts of TNF- $\alpha$, leading to skin changes (Clark \& Kupper, 2006).

\subsection{Dysfunction of the adaptive immune response cells}

Until the 1990s, psoriasis was thought to be a disease of disordered keratinoctye proliferation and differentiation (G. G. Krueger et al., 1984) and epidermal hyperplasia was the most prominent clinical and histological feature. For this reason, the old psoriasis treatments using antimetabolites including methotrexate which limit epidermal hyperproliferation. However, successive evidence from clinical studies and, experimental models support the theory that psoriasis is a $\mathrm{T}$ cell-mediated inflammatory skin disease (Lew et al., 2004) affecting genetically predisposed individuals and the epidermal hyperplasia is an effect of cellular immune infiltration.

\subsubsection{Role of $T$ cells}

The first evidence resulting in psoriasis being widely considered as a $\mathrm{T}$ cell mediated autoimmune disease came from the success in the psoriasis treatment of $\mathrm{T}$ cell-targeted therapies such as cyclosporine (Baker et al., 1987), tacrolimus (Jegasothy et al., 1992) or CD4specific monoclonal antibodies (Moabs) (J. Prinz et al., 1991).

A pivotal study involved the testing of IL-2-diphtheria-toxin fusion protein in psoriasis patients (S. L. Gottlieb et al., 1995). This agent selectively depleting activated T cells that express IL-2 receptors from psoriasis skin lesions and resulted in clinical remission of psoriasis vulgaris.

Subsequently, administration of another fusion protein, cytotoxic T-lymphocyte antigen 4 (CTLA4)-antibody, was shown to reverse the clinical and cellular features of psoriasis 
(Abrams et al., 1999). This agent blocks $\mathrm{T}$ cell co-stimulation mediated by DCs without directly deplete $\mathrm{T}$ cells. Its effectiveness indicated that continuing $\mathrm{T}$ cell co-stimulation is required to sustain psoriasis disease activity, including the excessive infiltration of $\mathrm{T}$ cells and DCs into the skin (Abrams et al., 2000). All these clinical results confirmed that lesionassociated $\mathrm{T}$ cells are central to sustaining disease activity in psoriasis.

Additional evidence highlighting the implication of $\mathrm{T}$ cells in psoriasis pathogenesis have been reviewed (Nestle et al., 2009) including the appearance of clonal T cells in psoriatic lesions (Menssen et al., 1995); the development of psoriasis-form phenotype within symptomless psoriatic skin after transplantion onto the xenotransplantation AGR 129 mouse model again underlines the importance of epidermal $\mathrm{T}$ cells in psoriasis genesis (Conrad et al., 2007).

Also, based on the findings that expansion of skin resident $\mathrm{T}$ cells is important in psoriasis progress in the xenotransplantation AGR mouse model, the function of tissue-specific factors in activation and expansion of resident $\mathrm{T}$ cells has been further explored (Conrad et al., 2007). T cells need to pass through the dermo-epidermal junction in order to go into the epidermis and collagen fibrils are an essential part of the dermo-epidermal junction. The most important basement membrane collagen is collagen IV and long-term activation of T cells results in the expression of a receptor for collagen IV, the heterodimeric integrin $\alpha 1 \beta 1$. It has been shown that epidermal accumulation of $\alpha 1 \beta 1^{+}$Th1 and Tc1 cells correlate with psoriasis development. Blocking $\alpha 1 \beta 1$ with a neutralizing Moab prevents epidermal $\mathrm{T}$ cell accumulation and subsequent psoriasis development in the xenotransplantation AGR mouse model. $\alpha 1 \beta 1$ expression can act as a checkpoint for entry of $\mathrm{T}$ cells into epidermis with $\alpha 1 \beta 1^{+}$epidermal $\mathrm{T}$ cells potentially playing an important role in psoriatic lesion formation.

In conclusion, targeting of these integrins may offer new and effective therapeutic approaches in psoriasis.

\subsubsection{The IL-23/Th17 pathway}

The IL-23/Th17 pathway is an exciting area in psoriatic pathology (Figure1) because it has led to the development of promising innovative treatments which specifically target this pathway (D'Elios et al., 2010). The development, characterization and function of Th17 cells and the role of IL-23 in Th17-cell dependent chronic inflammation in psoriasis have been recently reviewed (Di Cesare et al., 2009). Briefly, IL-23 is a heterodimeric cytokine (Oppmann et al., 2000) composed of the subunits IL-23p19 and IL-12p40 (an IL-12 subunit). Intradermal injection of IL-23 in mice resulted in the development of a psoriasis-form phenotype with histopathological features (Chan et al., 2006). IL-23 can mediate epidermal hyperplasia, acanthosis, hyperparakeratosis and orthohyperkeratosis by way of TNF- $\alpha$, IL20R2 and IL-22 (Chan et al., 2006; Zheng et al., 2007). These data are supported by findings in humans including an mRNA over-expression of IL-23p19 and IL-12p40 seen in psoriatic skin lesions, compared to uninvolved skin. Further other results indicate that IL -23 production occurs at inflammatory skin sites and is mediated by tissue-resident and/or recruited immune cells, such DCs and KCs (Piskin et al., 2006).

The pathogenic role of IL-23 in psoriasis is strongly supported by the clinical findings that anti-TNF- $\alpha$ agents can reduce IL-23p19 and IL-12p40 mRNA levels also the reduction of IL- 
23 level caused by cyclosporin A, UV therapy and biological agents correlates to clinical improvements in psoriasis patients (A. L. Gottlieb et al., 2005; Haider et al., 2008; Piskin et al., 2004).

Transforming growth factor (TGF)- $\beta 1$, IL-6 and IL-21 are all required to transform naïve T cells into cells expressing the unique lineage-specific transcription factor, RORC variant 2 and IL-23 receptors with subsequent binding of IL-23 resulting in differentiation into Th17 cells.

Th17 cells in turn produce the pro-inflammatory cytokines IL-17A, IL-17F, IL-22 and IL-26 (Langrish et al., 2005) that activate KCs leading to hyperproliferation and production of proinflammatory cytokines / chemokines, which recruit and activate other immune cells in the inflamed skin, enlarging the inflammatory response and consequently the clinical disease features. Another support for a role of the IL-23/Th17 pathway in psoriasis comes from whole genome studies showing that genetic variants of the IL-23 receptor are associated with psoriasis (Capon et al., 2007).

Regarding the clinical relevance of the IL-23/Th17 pathway, targeting the common subunit p40 of IL-12 and IL-23 demonstrated clinical improvement in psoriasis. Two anti-IL-12p40 Moabs, ustekinumab and ABT-874, have been recently developed as psoriasis cures. As we'll see in more detail later, ustekinumab and ABT-874 are humanized IgG1 Moabs that binding to the p40 subunit of human IL-12 and IL-23, prevents interaction with IL-12Rb1. Phase I (Kauffman et al., 2004) and phase II (Kimball et al., 2008b; G. G. Krueger et al., 2007) studies supported the use of both antibodies as effective treatments for psoriasis.

The safety profile of ustekinumab in psoriasis has been evaluated in 2 phase III studies. Of these, PHOENIX I assessed the efficacy and safety of ustekinumab 45 and $90 \mathrm{mg}$ administered subcutaneously at weeks 0,4 , and then every 12 weeks over 76 weeks of treatment (Leonardi et al., 2008). $67.1 \%$ and $66.4 \%$ of patients who received ustekinumab $45 \mathrm{mg}$ and $90 \mathrm{mg}$ respectively, achieved PASI-75 at week 12 compared to placebo control $(3.1 \%)$. The observed adverse events were mild, non-life threatening and not significantly different from the placebo group. The most commonly reported adverse events were upper respiratory tract infections, nasopharyngitis, headache, and arthralgia. The PHOENIX II trial (Papp et al., 2008) was conducted to further assess if dosing intensification would increase the response to treatment in partial responder patients (between PASI-50 and PASI-75). It was found that dosing intensification resulted in increased clinical efficacy only in patients receiving $90 \mathrm{mg}$, but not $45 \mathrm{mg}$, of ustekinumab every 8 weeks (PASI-75 in $68.8 \%$ of patients receiving $90 \mathrm{mg}$ every 8 weeks versus $33.3 \%$ of patients receiving $90 \mathrm{mg}$ every 12 weeks). The incidence and type of adverse events observed did not differ between PHOENIX I and II studies. Ustekinumab is also effective in the treatment of psoriatic arthritis and this study again confirmed that ustekinumab is well tolerated (A. Gottlieb et al., 2009).

\subsubsection{Regulatory $\mathrm{T}$ cells}

Regulatory $\mathrm{T}$ cells (Tregs) are characterized by their ability to suppress the activation and proliferation of effector T cells $\left(\mathrm{CD} 4^{+} / \mathrm{CD}^{+}\right)$by direct contact with antigen presenting cells (Gondek et al., 2005) or by releasing IL-10 (Annacker et al., 2003) and/or TGF- $\beta 1$ (Nakamura et al., 2004) (Figure 3). 
Tregs express CD4, height CD25 and Foxp3 and are about the 1-5 \% of the total population of peripheral $\mathrm{CD}^{+}$cells.

Dysfunction of Tregs has been implicated in the pathogenesis of various autoimmune diseases such as multiple sclerosis and rheumatoid arthritis (RA) and in psoriasis; where Treg function and proliferation are both defective (Sugiyama et al., 2005). This combination may result in a failure to limit the activation and proliferation of pathogenic $\mathrm{T}$ cells, contributing to the ongoing inflammation seen in psoriasis; for this reason strategies that correct Treg function or increase the Treg/pathogenic $\mathrm{T}$ cell ratio may be potential treatments for psoriasis (Sugiyama et al., 2005). Phototherapy, for example, might induce Treg type suppressor cells as well as eliminate pathogenic T cells (Baadsgaard et al., 1990), supporting a possible role of Treg cells in protection against psoriasis.

\section{Principal co-morbidities}

Today we know that during the time course of psoriasis, certain conditions may appear at somewhat unpredictable time points in a progressive fashion. These so-called comorbidities, often become manifest years after the onset of skin manifestations and are frequently observed in severe forms of psoriasis.

\subsection{Psoriatic arthritis}

PsA is traditionally included among common co-morbidities of psoriasis, even if it should be rather considered a component of the clinical spectrum of psoriatic disease. Skin manifestations occur before the onset of arthritis in the large majority of patients (A. B. Gottlieb et al., 2006), and in general, the prevalence of arthritis in psoriasis patients is estimated to be approximately 30\% (Gisondi et al., 2005; Zachariae et al., 2002).

In PsA pathogenesis the TNF- $\alpha$ plays a key role, promoting osteoclastogenesis and bone resorption by stimulating the receptor-activator of $\mathrm{NFkB}$, expressed in bone marrow osteoclast precursors (Abu-Amer et al., 2000; Keffer et al., 1991). Moreover, TNF- $\alpha$ has been noted to increase DKK-1 (dickkopf-1), a glycoprotein able to inhibit the bone apposition process by obstructing osteoblast growth (Baron \& Rawadi, 2007; Diarra et al., 2007).

Numerous clinical observations support these experimental data, particularly a number of clinical trials showed a significant inhibition of joint damage in patients who underwent anti-TNF therapy, confirming the role of TNF in altered bone remodeling.

Approximately $20 \%$ of PsA patients are estimated to suffer from a severe and destructive form of arthritis, that leads to overall increased disability (D. D. Gladman et al., 1990; Queiro-Silva et al., 2003). Interestingly, different results indicate that the DMARDs (diseasemodifying antirheumatic drugs) might not be able to inhibit disease progression and osteoarticular damage, even though they are generally useful in providing relief of clinical symptoms (Kana et al., 2003).

There is also convincing evidence of increased mortality in PsA patients, which seems to be related to disease activity, characterized by high erythrosedimentation rate, high medication level, and significant radiological damage at early patient visits (D. D. Gladman et al., 1998). Fortunately, as we shall see later, the mortality in PsA patients has gradually improved by using the biological drugs (Ali et al., 2007). 


\subsection{Inflammatory bowel disease (IBD)}

IBD commonly refers to ulcerative colitis (UC) and Crohn's disease (CD), which are chronic inflammatory diseases of the gastrointestinal tract with unknown etiology. UC and $C D$ have significant clinical differences, however, both diseases share similar pathogenic mechanisms and many extra-intestinal manifestations, and frequently respond to the same treatments.

Many data indicate a stringent correlation between CD and psoriasis (Najarian \& A. B. Gottlieb, 2003). Firstly, CD patients have been found to have a seven-fold higher risk of developing psoriasis than control subjects (Mrowietz et al., 2006). This association may be related to the following observations: a) it has been shown that TNF- $\alpha$ has a key role in both conditions, valuing the hypothesis of common inflammatory pathways. This point has been further supported by the therapeutic efficacy of anti-TNF- $\alpha$ antibodies; $b$ ) genetic evidences, such as polymorphisms in the TNF- $\alpha$ promoter region and the close position of the susceptibility loci, link psoriasis to CD (Najarian \& A. B. Gottlieb, 2003). In particular, a recent study demonstrated a significant association between CD and the IL-23 receptor gene (Duerr et al., 2006) and, as reported previously, IL-23 /IL-17 pathway is involved in psoriasis pathogenesis (Blauvelt, 2008; Rizzo et al., 2011).

On the other hand, the association between psoriasis and UC has been described in only in recent studies, even if the first studies regarding this connection trace back to the 60s and early 70s (Brewerton et al., 1974; McEwen et al., 1971). Most recently, Cohen et coll. (Cohen et al., 2009), in a case-control study with 12,502 psoriasis patients, demonstrated that even though not as high as CD (odds ratio 2.49), UC association is statistically significant and far from being negligible (odds ratio 1.64). This often undervalued correlation is biologically conceivable because chronic systemic inflammation and TNF- $\alpha$ constitute core features of UC, as well as psoriasis (Torres \& Rios 2008).

\subsection{Metabolic Syndrome (MS) and Cardiovascular Diseases (CVD)}

Different overlapping guidelines have been proposed to define the MS: the cardiometabolic risk factors of obesity, impaired glucose tolerance (or type 2 diabetes), insulin resistance, dyslipidemia, and hypertension (Alberti et al., 2006; Grundy et al., 2005; Johnson \& Weinstock, 2006). Just like psoriasis, MS is characterized by a pro-inflammatory state, characterized by a complex cytokines network.

In response to various metabolic signals the adipose tissue release the adipokines that modulate flogosis, lipid metabolism, and insulin sensitivity. A cluster of these adipokines is represented by pro-inflammatory cytokines (TNF- $\alpha$, IL-8 and IL-6) whose overproduction drives the psoriasis pathogenesis, as well as of certain basic features of MS like insulin resistance and diabetes (Arican et al., 2005; Nickoloff \& Nestle, 2004; Rondinone, 2006). Consistent with this common pathophysiology, different studies have demonstrated that psoriasis patients show an increased risk of developing the metabolic syndrome (Henseler \& Christophers, 1995; Neimann et al., 2006).

The multiple conditions that constitute the MS could very well be the main reasons for CVD in psoriasis patients. 
However, in various studies involving patients with psoriasis, the latter was identified as an independent risk factor for myocardial infarction regardless of the presence of the complete MS and an independent risk factor for coronary artery calcification (Gelfand et al., 2006).

Indeed, as of today there is forceful evidence that psoriasis, much like other systemic proinflammatory conditions (e.g. RA, SLE), may predispose to an increased CVD risk, following a nontraditional pathway to atherogenesis and premature vascular damage (Kimball et al., 2008c; Saphiro et al., 2007).

In conclusion, basic inflammatory activity in psoriasis could act independently of traditional risk factors, MetS included, and can increase the risk of CVD through its own underlying biological mechanisms (inflammation-driven atherogenesis).

\begin{tabular}{|c|c|c|}
\hline Cell Types & Biological Effects & Clinical Consequences \\
\hline Leukocytes & $\begin{array}{l}\text { Activation/maturation } \\
\uparrow \text { inflammatory } \\
\text { cytokine/expression } \\
\text { ROS release }\end{array}$ & $\begin{array}{l}\uparrow \text { Inflammation } \\
\text { Endothelial injury } \\
\text { Epidermal Proliferation }\end{array}$ \\
\hline Endothelial cells & $\begin{array}{l}\text { Suppression of precursor } \\
\text { cells/apoptosis } \\
\uparrow \text { expression of adhesion } \\
\text { molecules } \\
\uparrow \text { release of VEGF } \\
\text { Impaired NO Bioavailability } \\
\text { Induction of TF expression }\end{array}$ & $\begin{array}{l}\uparrow \text { Angiogenesis } \\
\uparrow \text { leukocytes recruitment } \\
\text { Endothelian dysfunction } \\
\text { Hemostasis impairment }\end{array}$ \\
\hline Osteoclast precursors & $\begin{array}{l}\uparrow \mathrm{RANKL} \text { expression } \\
(\uparrow \text { osteoclast } \\
\text { maturation/activation) } \\
\uparrow \text { DKK-1 level ( } \downarrow \text { osteoclast } \\
\text { development) }\end{array}$ & $\begin{array}{l}\text { Bone resorption promotion } \\
\text { Bone apposition inhibition }\end{array}$ \\
\hline Condrocytes/Synoviocytes & $\begin{array}{l}\text { Apoptosis } \\
\uparrow \text { Metalloproteinase synthesis }\end{array}$ & Articular erosion \\
\hline Adipocytes & $\begin{array}{l}\text { Dysregulation of lipid and } \\
\text { glucose metabolism } \\
\uparrow \text { circulating levels of FFA } \\
\text { and LDL }\end{array}$ & $\begin{array}{l}\text { Disadvantageous metabolic } \\
\text { response to injury and } \\
\text { infection } \\
\uparrow \text { in traditional CV risk } \\
\text { factors }\end{array}$ \\
\hline Hepatocytes & Induction of IL-6 & $\begin{array}{l}\text { Raised CRP serum levels } \\
\text { CRP-induced vascular } \\
\text { dysfunction }\end{array}$ \\
\hline Neural cells & $\begin{array}{l}\text { Modulation of cell } \\
\text { proliferation NGF-induced }\end{array}$ & Neurogenic inflammation \\
\hline
\end{tabular}

$\uparrow=$ Increase; $\downarrow$ = decrease; CRP = C-reactive protein; CV = Cardiovascular; DKK-1 = Dickkopf-1; LDL = Low-density lipoproteins; NGF $=$ Nerve growth factor; $\mathrm{NO}=$ Nitric oxide; RANKL $=$ Receptor-

Activator of NFkappaB ligand; ROS = Reactive oxygen species; TF = Tissue Factor; VEGF = Vascular endothelial growth factor.

Table 1. Biological effects and clinical consequences of TNF- $\alpha$ stimulation in different cells 
Recently, some studies have also shown that in psoriasis patients, the increased risk for myocardial infarction varies by age (higher in younger individuals) and disease severity (higher in severe forms) (Gelfand et al., 2006; Kremers et al., 2007; Mallbris et al., 2004). As such, a young patient with severe psoriasis is burdened by a CVD risk comparable with what is seen in the presence of traditional risk factors such as diabetes and hypertension.

Moreover, a variety of data indicates that psoriasis and CVD (mostly atherosclerosis) share common pathogenic features: both Th1 mediated, with an up-regulation of Th1 cytokines (TNF- $\alpha$, IFN- $\gamma$ ) and a systemic expression of adhesion molecules, neoangiogenesis factors, and superantigens, these latter potentially able to activate the T cells (Biedermann et al., 2004; Ettehadi et al., 2004; Gudjonsson et al., 2004). The table 1 summarizes the consequences of the TNF- $\alpha$ over-expression in promoting inflammatory conditions such as psoriasis and atherogenesis.

Overlapping of genetic susceptibility loci between psoriasis and atherosclerosis is also worth mentioning, even though its role has yet to be fully understood (Becker et al., 1998).

Lastly, the two conditions also show similar histological aspects, mainly involving $\mathrm{T}$ cells, macrophages, mast cells and connective tissue matrix. (Nickoloff et al., 2007a; Nickoloff et al., 2007b).

Alongside the similar pathogenesis, other indirect factors might be responsible for psoriasisCVD association; in fact some authors have found that a number of conventional systemic psoriasis treatments (e.g. methotrexate, acitretin, cyclosporine) might increase the effects of specific CVD risk factors (Katz et al., 1994; Strober \& Menon, 2005; Taler et al., 1999).

\section{Disease evaluation}

To assess the severity of psoriasis and PsA (baseline/in response to treatment), a number of tools are now available, of which the Psoriasis Activity and Severity Index (PASI) is the most frequently used (Fredriksson \& Pettersson, 1978). The PASI combines assessments of the extent of body surface involvement in four anatomical regions (head, trunk, arms and legs) and the severity of desquamation, erythema and plaque induration (thickness) in each region, yielding an overall score of 0 (no psoriasis) to 72 (severe psoriasis) (Fredriksson \& Pettersson, 1978). PASI 75 is defined as a $75 \%$ reduction in PASI compared with baseline, instead a PASI score of $>10$ is defined as moderate to severe disease, necessitating systemic therapy (PUVA, UVB 311, MTX, cyclosporin A or biological drugs) (Pathirana et al., 2009)

An additional tool to assess the psoriasis severity is the physician's global assessment (PGA). The PGA takes into account the involvement of the body surface area, induration, scaling and erythema and grades the patient's psoriasis overall, relative to baseline, as 1 (clear), 2 (excellent), 3 (good), 4 (fair), 5 (poor) or 6 (worse) (Pathirana et al., 2009).

In trials investigating patients with PsA, the American College of Rheumatology Criteria (ACR) are most commonly used. The ACR clinical response criteria are defined as percentage reduction [20\% (ACR 20), 50\% (ACR50) and 70\% (ACR 70)] in tender and swollen joint counts and in 3 of the, remaining, 5 ACR core items (patient and physician global assessments, pain, disability and an acute phase reactant) (Montecucco, 2006; Radtke et al., 2009). 
A supplementary tool to evaluate clinical remission in psoriatic patients is the Disease Activity Score (DAS) comprising the number of swollen and tender joints, the erythrocyte sedimentation rate and the general health of the patient (measured on a visual analogue scale) (Montecucco, 2006). The DAS measures 44 swollen joints, whereas the modified DAS 28 measures only 28 swollen and tender joints (Prevoo et al., 1995). The effect of psoriasis on the patient's quality of life is measured by the 10-item Dermatology Life Quality Index (DLQI) questionnaire. DLQI scores range from 0 (not at all) to 30 (very much) (Pathirana et al., 2009).

\section{Biological drugs}

Biological therapies for the treatment of psoriasis are defined by their mode of action and are classified into 3 groups, the inhibitors of TNF- $\alpha$ (adalimumab, certolizumab, etanercept, golimumab, and infliximab), the T-cell modulating agents (such as alefacept) and the inhibitors of IL-12 and IL-23 (ustekinumab and briakinumab).

\subsection{TNF- $\alpha$ inhibitors}

The TNF- $\alpha$ inhibitors adalimumab, etanercept and infliximab have been approved by the FDA and EMEA for psoriasis and PsA treatment; they have been reviewed quite extensively in the past and the table 2 summarizes the clinical outcome for primary endpoints (e.g. PASI and ACR) in randomized controlled studies.

In this chapter, instead will focus on the new TNF- $\alpha$ blockers such as golimumab and certolizumab (Mössner et al., 2008; Pathirana et al., 2009).

\begin{tabular}{|c|c|c|c|c|c|}
\hline Drug & Disease & Trial Type & $\begin{array}{c}\text { Treatment } \\
\left(n^{\circ} \text { of patients) }\right.\end{array}$ & $\begin{array}{l}\text { Major } \\
\text { Results }\end{array}$ & References \\
\hline Adalimumab & Psoriasis & $\begin{array}{l}\text { 12-week } \\
\text { RDBPC } \\
\text { OLE until } \\
\text { week } 60\end{array}$ & $\begin{array}{l}\text { A } 40 \text { mg weekly } \\
\text { (50) } \\
\text { A } 40 \text { mg eow } \\
\text { (46) } \\
\text { Placebo (52) }\end{array}$ & $\begin{array}{l}\text { PASI } 75 \text { at } \\
\text { week 12: } 80 \\
\text { PASI } 75 \text { at } \\
\text { week 12: } 53 \\
\text { PASI } 75 \text { at } \\
\text { week 12: } 4\end{array}$ & $\begin{array}{l}\text { Gordon et } \\
\text { al.,2006 } \\
\text { J Am Acad } \\
\text { Dermatol 55: } \\
\text { 598-606. }\end{array}$ \\
\hline $\begin{array}{l}\text { Adalimumab } \\
\text { (REVEAL) }\end{array}$ & Psoriasis & $\begin{array}{l}\text { 16-week } \\
\text { RDBPC } \\
\text { OLE until } \\
\text { week } 52\end{array}$ & $\begin{array}{l}\text { A } 40 \text { mg eow } \\
(814) \\
\text { Placebo (398) }\end{array}$ & $\begin{array}{l}\text { PASI } 75 \text { at } \\
\text { week 16: } 71 \\
\text { PASI } 75 \text { at } \\
\text { week 16: } 7\end{array}$ & $\begin{array}{l}\text { Menter et al., } \\
2008 \\
\text { J Am Acad } \\
\text { Dermatol 58: } \\
106-115 .\end{array}$ \\
\hline $\begin{array}{l}\text { Adalimumab } \\
\text { (CHAMPION) }\end{array}$ & Psoriasis & $\begin{array}{l}\text { 16-week } \\
\text { RDBPC }\end{array}$ & $\begin{array}{l}\text { A } 40 \text { mg eow } \\
(108) \\
\text { MTX (110) } \\
\text { Placebo (53) }\end{array}$ & $\begin{array}{l}\text { PASI } 75 \text { at } \\
\text { week 16: } 80 \\
\text { PASI } 75 \text { at } \\
\text { week 16: } 36 \\
\text { PASI 75 at } \\
\text { week 16: } 19\end{array}$ & $\begin{array}{l}\text { Saurat et al., } \\
2008 \\
\text { Br J Dermatol } \\
\text { 158: } \\
558-566 .\end{array}$ \\
\hline $\begin{array}{l}\text { Adalimumab } \\
\text { (ADEPT) }\end{array}$ & $\begin{array}{l}\text { Psoriasis } \\
\text { arthritis }\end{array}$ & $\begin{array}{l}\text { 24-week } \\
\text { RDBPC } \\
\text { OLE }\end{array}$ & $\begin{array}{l}\text { A } 40 \text { mg eow } \\
\text { (151) } \\
\text { Placebo (162) }\end{array}$ & $\begin{array}{l}\text { ACR } 20 \text { at } \\
\text { week 12: } 58 \\
\text { ACR 20 at } \\
\end{array}$ & $\begin{array}{l}\text { Mease et al., } \\
2005 \\
\text { Arthritis Rheum }\end{array}$ \\
\hline
\end{tabular}




\begin{tabular}{|c|c|c|c|c|c|}
\hline & & $\begin{array}{l}\text { OLE week } \\
48 \\
\text { OLE week } \\
104\end{array}$ & OLE A (281) & $\begin{array}{l}\text { week 12: } 14 \\
\text { ACR 20 at } \\
\text { week 48: } 58.7 \\
\text { ACR } 20 \text { at } \\
\text { week 104: } \\
57.3\end{array}$ & $\begin{array}{l}\text { 52: } \\
\text { 3279-3289. } \\
\text { Gladman et al., } \\
2007 \\
\text { Arthris Rheum } \\
\text { 56: } \\
\text { 476-488. } \\
\text { Mease et al., } \\
2009 \\
\text { Ann Rheum Dis } \\
\text { 68: } \\
702-709 .\end{array}$ \\
\hline Adalimumab & $\begin{array}{l}\text { Psoriasis } \\
\text { arthritis }\end{array}$ & $\begin{array}{l}\text { 12-week } \\
\text { RDBPC } \\
\text { OLE until } \\
\text { week } 24\end{array}$ & $\begin{array}{l}\text { A } 40 \text { mg eow } \\
(51) \\
\text { Placebo (49) }\end{array}$ & $\begin{array}{l}\text { ACR } 20 \text { at } \\
\text { week 12: } 39 \\
\text { ACR 20 at } \\
\text { week 12: } 16\end{array}$ & $\begin{array}{l}\text { Genovese et al., } \\
2007 \\
\text { J Rheumatol 34: } \\
\text { 1040-1050. }\end{array}$ \\
\hline Etanercept & Psoriasis & $\begin{array}{l}\text { 12-week } \\
\text { RDBPC }\end{array}$ & $\begin{array}{l}\text { E } 25 \text { mg twice } \\
\text { weekly (57) } \\
\text { Placebo (55) }\end{array}$ & $\begin{array}{l}\text { PASI } 75 \text { at } \\
\text { week 12: } 30 \\
\text { PASI } 75 \text { at } \\
\text { week 12: } 2\end{array}$ & $\begin{array}{l}\text { Gottlieb et al., } \\
2003 \\
\text { Arch Dermatol } \\
139: \\
1563-1570 .\end{array}$ \\
\hline $\begin{array}{l}\text { Etanercept } \\
\text { CONSORT }\end{array}$ & Psoriasis & RDBPC & $\begin{array}{l}\text { E } 25 \text { mg twice } \\
\text { weekly (196) } \\
\text { E } 50 \text { mg twice } \\
\text { weekly (194) } \\
\text { Placebo (193) }\end{array}$ & $\begin{array}{l}\text { PASI } 75 \text { at } \\
\text { week 12: } 34 \\
\text { PASI } 75 \text { at } \\
\text { week 12: } 49 \\
\text { PASI } 75 \text { at } \\
\text { week 12: } 3\end{array}$ & $\begin{array}{l}\text { Papp et al., } \\
2005 \\
\text { Br J Dermatol } \\
\text { 152: } \\
1304-1312 .\end{array}$ \\
\hline Etanercept & Psoriasis & RDBPC & $\begin{array}{l}\text { E } 25 \text { mg weekly } \\
(160) \\
\text { E } 25 \text { mg twice } \\
\text { weekly (162) } \\
\text { E } 50 \mathrm{mg} \text { twice } \\
\text { weekly (164) } \\
\text { Placebo (166) }\end{array}$ & $\begin{array}{l}\text { PASI } 75 \text { at } \\
\text { week 12: } 14 \\
\text { PASI } 75 \text { at } \\
\text { week 12: } 34 \\
\text { PASI } 75 \text { at } \\
\text { week 12: } 49 \\
\text { PASI 75 at } \\
\text { week 12: } 4\end{array}$ & $\begin{array}{l}\text { Leonardi et al., } \\
2003 \\
\text { N Engl J Med } \\
\text { 349: } \\
2014-2022 .\end{array}$ \\
\hline Etanercept & Psoriasis & $\begin{array}{l}\text { 12-week } \\
\text { RDBPC }\end{array}$ & $\begin{array}{l}\text { E } 50 \text { mg twice } \\
\text { weekly (311) } \\
\text { Placebo (307) }\end{array}$ & $\begin{array}{l}\text { PASI } 75 \text { at } \\
\text { week 12: } 47 \\
\text { PASI } 75 \text { at } \\
\text { week 12: } 5\end{array}$ & $\begin{array}{l}\text { Tyring et al., } \\
2006 \\
\text { Lancet 367: 29- } \\
35 .\end{array}$ \\
\hline Etanercept & $\begin{array}{l}\text { Psoriasis } \\
\text { arthritis }\end{array}$ & $\begin{array}{l}\text { 12-week } \\
\text { RDBPC }\end{array}$ & $\begin{array}{l}\text { E } 25 \text { mg twice } \\
\text { weekly (30) } \\
\text { Placebo (30) }\end{array}$ & $\begin{array}{l}\text { ACR } 20 \text { at } \\
\text { week 12: } 73 \\
\text { ACR 20 at } \\
\text { week 12: } 13\end{array}$ & $\begin{array}{l}\text { Mease et al., } \\
2000 \\
\text { Lancet 356: } \\
385-390 .\end{array}$ \\
\hline Etanercept & $\begin{array}{l}\text { Psoriasis } \\
\text { arthritis }\end{array}$ & $\begin{array}{l}\text { 24-week } \\
\text { RDBPC } \\
\text { OLE until } \\
\text { week } 48\end{array}$ & $\begin{array}{l}\text { E } 25 \text { mg twice } \\
\text { weekly (101) } \\
\text { Placebo (104) }\end{array}$ & $\begin{array}{l}\text { ACR 20 at } \\
\text { week 12: } 59 \\
\text { ACR 20 at } \\
\text { week 12: } 15\end{array}$ & $\begin{array}{l}\text { Mease et al., } \\
2004 \\
\text { Arthritis Rheum } \\
\text { 50: } \\
2264-2272 .\end{array}$ \\
\hline
\end{tabular}




\begin{tabular}{|c|c|c|c|c|c|}
\hline $\begin{array}{l}\text { Infliximab } \\
\text { SPIRIT }\end{array}$ & Psoriasis & RDBPC & $\begin{array}{l}\text { I } 3 \text { mg ·kg-1 (99) } \\
\text { I } 5 \text { mg kg-1 (99) } \\
\text { Placebo (51) }\end{array}$ & $\begin{array}{l}\text { PASI } 75 \text { at } \\
\text { week 10: } 72 \\
\text { PASI } 75 \text { at } \\
\text { week 10: } 88 \\
\text { PASI } 75 \text { at } \\
\text { week 10: } 6\end{array}$ & $\begin{array}{l}\text { Gottlieb et al., } \\
2004 \\
\text { J Am Acad } \\
\text { Dermatol 51: } \\
534-542 .\end{array}$ \\
\hline $\begin{array}{l}\text { Infliximab } \\
\text { EXPRESS I }\end{array}$ & Psoriasis & RDBPC & $\begin{array}{l}\text { I } 5 \text { mg } \cdot k g-1 \\
(301) \\
\text { Placebo (77) }\end{array}$ & $\begin{array}{l}\text { PASI } 75 \text { at } \\
\text { week 10: } 80 \\
\text { PASI } 75 \text { at } \\
\text { week 10: } 3\end{array}$ & $\begin{array}{l}\text { Reich et al., } \\
2005 \\
\text { Lancet } \\
\text { 366: 1367-1374. }\end{array}$ \\
\hline Infliximab & Psoriasis & RDBPC & $\begin{array}{l}\text { I } 5 \text { mg kg-1 (11) } \\
\text { I } 10 \text { mg kg-1 } \\
\text { (11) } \\
\text { Placebo (11) }\end{array}$ & $\begin{array}{l}\text { PASI } 75 \text { at } \\
\text { week 10: } 82 \\
\text { PASI 75 at } \\
\text { week 10: } 73 \\
\text { PASI 75 at } \\
\text { week 10: } 18\end{array}$ & $\begin{array}{l}\text { Chaudhari et } \\
\text { al., 2001 } \\
\text { Lancet 357: } \\
\text { 1842-1847. }\end{array}$ \\
\hline $\begin{array}{l}\text { Infliximab } \\
\text { EXPRESS II }\end{array}$ & Psoriasis & RDBPC & $\begin{array}{l}\text { I } 3 \text { mg kg-1 } \\
(311) \\
\text { I } 5 \text { mg kg-1 } \\
(314) \\
\text { Placebo (208) }\end{array}$ & $\begin{array}{l}\text { PASI } 75 \text { at } \\
\text { week 10: } 70 \\
\text { PASI } 75 \text { at } \\
\text { week 10: } 76 \\
\text { PASI 75 at } \\
\text { week 10: } 2\end{array}$ & $\begin{array}{l}\text { Menter et al., } \\
2007 \\
\text { J Am Acad } \\
\text { Dermatol 56: } \\
\text { 31.e1-31.e5. }\end{array}$ \\
\hline $\begin{array}{l}\text { Infliximab } \\
\text { IMPACT }\end{array}$ & $\begin{array}{l}\text { Psoriasis } \\
\text { arthritis }\end{array}$ & $\begin{array}{l}\text { 16-week } \\
\text { RDBPC } \\
\text { OLE week } \\
50\end{array}$ & $\begin{array}{l}\text { I } 5 \text { mg kg-1 (52) } \\
\text { Placebo (52) }\end{array}$ & $\begin{array}{l}\text { ACR } 20 \text { at } \\
\text { week } 16: 65 \\
\text { ACR } 20 \text { at } \\
\text { week } 16: 10\end{array}$ & $\begin{array}{l}\text { Antoni et al., } \\
2005 \\
\text { Arthritis Rheum } \\
\text { 52: } \\
1227-1236 .\end{array}$ \\
\hline $\begin{array}{l}\text { Infliximab } \\
\text { IMPACT II }\end{array}$ & $\begin{array}{l}\text { Psoriasis } \\
\text { arthritis }\end{array}$ & $\begin{array}{l}\text { 24-week } \\
\text { RDBPC } \\
\text { OLE } 52 \\
\text { weeks }\end{array}$ & $\begin{array}{l}\text { I } 5 \text { mg } \cdot k g-1 \\
(100) \\
\text { Placebo (100) }\end{array}$ & $\begin{array}{l}\text { ACR } 20 \text { at } \\
\text { week 24: } 54 \\
\text { ACR 20 at } \\
\text { week 24: } 16\end{array}$ & $\begin{array}{l}\text { Kavanaugh et } \\
\text { al., } 2007 \\
\text { Ann Rheum Dis } \\
\text { 66: } \\
498-505 \text {. }\end{array}$ \\
\hline $\begin{array}{l}\text { Golimumab } \\
\text { GO-REVEAL }\end{array}$ & Psoriasis & $\begin{array}{l}\text { 24-week } \\
\text { RDBPC }\end{array}$ & $\begin{array}{l}\text { G } 50 \text { mg q4 wks } \\
(146) \\
\text { G } 100 \text { mg q4 } \\
\text { wks (146) } \\
\text { Placebo (113) }\end{array}$ & $\begin{array}{l}\text { PASI } 75 \text { at } \\
\text { week 14: } 40 \\
\text { PASI } 75 \text { at } \\
\text { week 14: } 58 \\
\text { PASI 75 at } \\
\text { week 14: } 3\end{array}$ & $\begin{array}{l}\text { Kavanaugh et } \\
\text { al., 2009 } \\
\text { Arthritis Rheum } \\
\text { 60: } \\
\text { 976-986. }\end{array}$ \\
\hline $\begin{array}{l}\text { Golimumab } \\
\text { GO-REVEAL }\end{array}$ & $\begin{array}{l}\text { Psoriasis } \\
\text { arthritis }\end{array}$ & $\begin{array}{l}\text { 24-week } \\
\text { RDBPC }\end{array}$ & $\begin{array}{l}\text { G } 50 \text { mg q4wks } \\
(146) \\
\text { G } 100 \mathrm{mg} \text { q4wks } \\
(146) \\
\text { Placebo (113) }\end{array}$ & $\begin{array}{l}\text { ACR } 20 \text { at } \\
\text { week 14: } 51 \\
\text { ACR } 20 \text { at } \\
\text { week 14: } 45 \\
\text { ACR } 20 \text { at } \\
\text { week 14: } 9\end{array}$ & $\begin{array}{l}\text { Kavanaugh et } \\
\text { al., 2009 } \\
\text { Arthritis Rheum } \\
\text { 60: } \\
\text { 976-986. }\end{array}$ \\
\hline
\end{tabular}

$\mathrm{A}=$ Adalimumab; $\mathrm{E}$ = Etanercept; $\mathrm{I}$ = Infliximab; $\mathrm{G}$ = Golimumab; OLE = Open Level Extension; q4 wks = every 4 weeks; RDBPC $=$ Randomized Double-Blind Placebo Controlled Trial

Table 2. Efficacy of anti-TNF- $\alpha$ in the treatment of psoriasis and psoriasis arthritis 
Up to now, treatment with MoaB anti-TNF- $\alpha$ has proven to be effective and relatively safe in patients with psoriasis and PsA (Lima et al., 2009).

Since TNF- $\alpha$ has showed an osteoclast stimulating effect, alongside being synergic with DKK-1 in reducing osteoblasts maturation, anti-TNF- $\alpha$ drugs should improve PsA-related bone altering processes, as confirmed by significant inhibition of radiographic progression during treatment with etanercept or infliximab (Antoni et al., 2008; Mease et al., 2006b; van der Heijde et al., 2007).

Equally importantly, anti-TNF- $\alpha$ therapy might have a preventive effect on PsA overlapping in psoriasis patients. In fact, in a case-control study, Gisondi group (Gisondi et al., 2008) has demonstrated that lower limb enthesopathy can be documented in asymptomatic psoriasis patients without any clinical sign of arthropathy. Similar findings were reported in the past concerning entheseal abnormalities (De Filippis et al., 2005) and increased Achilles tendon thickness (Ozcakar et al., 2005); all of which were detected in asymptomatic patients.

Different evidences have proved that anti-TNF- $\alpha$ treatments infliximab and adalimumab are effective in controlling gut inflammation, whereas etanercept is not (Bosani et al., 2009).

There are reports of CD development in patients with ankylosing spondylitis or PsA (Song et al., 2008) and treated with etanercept. However, it is well-known that such patients are burdened with a high risk of chronic IBD development. It is therefore hard to assess whether these cases of CD were really a consequence of anti-TNF- $\alpha$ therapy or rather a coincidental event in predisposed patients.

The reason for the discordant effect of anti-TNF- $\alpha$ treatments on IBD probably lies in different pharmacodynamic features of these drugs, and a number of hypotheses have been expressed in this regard.

Firstly, it has been noted that etanercept, unlike anti-TNF- $\alpha$ Moabs, doesn't induce apoptosis of activated lymphocytes in CD patients (Van den Brande et al., 2003). Given the existing results, it is reasonable to conclude that etanercept has no potential to control or to prevent gut inflammation and hence IBD appearance. A preventive role of anti-TNF- $\alpha$ Moabs against the IBD development in susceptible psoriasis patients cannot be rule out considering the effectiveness of these drugs in both conditions.

About the effects of anti-TNF-a Moabs in MS and CVD, studies regarding the consequence on blood lipids have shown unclear results. A study of RA patients reported a significant decreased atherogenic index of low-density lipoprotein (LDL)/high-densitiy lipoprotein (HDL) ratio after 6 months of therapy with anti-TNF-a (Spanakis et al., 2006); another showed increased HDL levels and reduced C-reactive protein (CRP) and IL-6 levels after 2 weeks (Popa et al., 2005). In contrast, in some cases anti-TNF-a therapy has resulted in a proatherogenic effect in RA and PsA patients, with increase of LDL/ HDL ratio and triglycerides levels (Dahlqvist et al., 2004). Another study demonstrated a sudden reduction in HDL levels the day after infliximab infusion, but without any significant variation in the HDL profile (Irace et al., 2004).

No conclusions can be drawn from these inconsistent findings regarding long-term clinical outcomes. As a consequence, many authors seem to agree on the fact that despite the prominent role of TNF- $\alpha$ on lipid regulation, the emerging efficacy of anti-TNF- $\alpha$ therapy 


\begin{tabular}{|c|c|c|c|}
\hline $\begin{array}{c}\text { Anti-TNF-a } \\
\text { therapy }\end{array}$ & $\begin{array}{c}\text { Frequent side } \\
\text { effects }\end{array}$ & Rare severe side effects & Reference \\
\hline Adalimumab & $\begin{array}{l}\text { - Upper respiratory } \\
\text { tract infections } \\
\text { - Injection site } \\
\text { reactions } \\
\text { - Headache }\end{array}$ & $\begin{array}{l}\text { - Severe/ Opportunistic } \\
\text { infections } \\
\text { - Reactivation/progression of } \\
\text { TBC } \\
\text { - Onset/exacerbation of CNS } \\
\text { demyelinating disorders } \\
\text { (e.g. Multiple Sclerosis) } \\
\text { - Increased risk of cancer } \\
\text { (e.g. Lymphoma) } \\
\text { - Drug-induced lupus } \\
\text { - Exacerbation of congestive } \\
\text { - heart failure }\end{array}$ & $\begin{array}{l}\text { Pathirana et al., } 2009 \\
\text { J Eur Acad Dermatol } \\
\text { Venerol } 23 \text { (Suppl. 2): } \\
\text { S5-70. } \\
\text { Smith et al., } 2009 \\
\text { Br J Dermatol } \\
\text { 161: 987-1019. }\end{array}$ \\
\hline Etanercept & $\begin{array}{l}\text { - Upper respiratory } \\
\text { tract infections } \\
\text { - Injection site } \\
\text { reactions } \\
\text { - Pruritus }\end{array}$ & $\begin{array}{l}\text { - Severe/ Opportunistic } \\
\text { infections } \\
\text { - Reactivation/progression of } \\
\text { TBC } \\
\text { - Onset/exacerbation of CNS } \\
\text { demyelinating disorders } \\
\text { (e.g. Multiple Sclerosis) } \\
\text { - Increased risk of cancer } \\
\text { (e.g. Lymphoma) } \\
\text { - Drug-induced lupus } \\
\text { - Exacerbation of congestive } \\
\text { heart failure } \\
\text { - Vasculitis } \\
\text { - Aplastic anaemia } \\
\end{array}$ & $\begin{array}{l}\text { Pathirana et al., } 2009 \\
\text { J Eur Acad Dermatol } \\
\text { Venerol } 23 \text { (Suppl. 2): } \\
\text { S5-70. } \\
\text { Smith et al., } 2009 \\
\text { Br J Dermatol } \\
\text { 161: 987-1019. }\end{array}$ \\
\hline Infliximab & $\begin{array}{l}\text { - Upper respiratory } \\
\text { tract infections } \\
\text { - Acute infusion } \\
\text { reaction: } \\
\text { - fever, chills, } \\
\text { nausea } \\
\text { - Headache } \\
\text { - Pruritus } \\
\text { - Urticaria } \\
\text { - Elevated } \\
\text { transaminases }\end{array}$ & $\begin{array}{l}\text { - Severe/ Opportunistic } \\
\text { infections } \\
\text { - Reactivation/progression of } \\
\text { TBC } \\
\text { - Onset/exacerbation of CNS } \\
\text { demyelinating disorders } \\
\text { (e.g. Multiple Sclerosis) } \\
\text { - Increased risk of cancer } \\
\text { (e.g. Lymphoma) } \\
\text { - Drug-induced lupus } \\
\text { - Exacerbation of congestive } \\
\text { heart failure } \\
\text { - Vasculitis } \\
\text { - Pancytopenia }\end{array}$ & $\begin{array}{l}\text { Pathirana et al., } 2009 \\
\text { J Eur Acad Dermatol } \\
\text { Venerol } 23 \text { (Suppl. 2): } \\
\text { S5-70. } \\
\text { Smith et al., } 2009 \\
\text { Br J Dermatol } \\
\text { 161: 987-1019. }\end{array}$ \\
\hline
\end{tabular}

Table 3. Overview of side effects of most prescribed anti-TNF-a treatments in patients with psoriasis 
on CV morbidity and mortality is likely independent of the induced blood lipid variations (Soubrier et al., 2008).

Results derived from studies about the effects of anti-TNF- $\alpha$ drugs on insulin resistance in psoriasis patients, appear to show an improvement in insulin sensitivity (Marra et al., 2007). This outcome seems to confirm the beneficial effects of anti-TNF- $\alpha$ Moabs already documented in many RA studies (Huvers et al., 2007; Yazdani-Biuki et al., 2004). In particular, infliximab has proved capable of enhancing insulin sensitivity after the infusion to up to one year (Huvers et al., 2007). Lastly, there have been few isolated cases of psoriasis patients with diabetes developing unpredictable hypo- or hyperglycemia after commencing treatment with TNF inhibitors (Boulton \& Bourne, 2007; Wu \& Tsai 2008).

In the table 3 are reported the side effects of adalimumab, etanercept and infliximab treatment in psoriasis patients.

\subsubsection{Golimumab (CNTO148)}

Golimumab is a human immunoglobulin G1K Moab binding both soluble and transmembrane forms of TNF- $\alpha$, thereby neutralizing their bioactivity by blocking the interaction with receptor (Kavanaugh et al., 2009; Xu et al., 2009).

In a study with 337 patients, the pharmacokinetics of subcutaneously administered golimumab (50 or $100 \mathrm{mg}$ every 4 weeks) were analyzed (Xu et al., 2009) and the following golimumab pharmacokinetic parameters were found: apparent clearance $=1.38 \pm 0.04 \mathrm{~L}$ per day, apparent volume of distribution $=24.9 \pm 1.04 \mathrm{~L}$ and absorption rate constant $=0.908 \pm$ 0.121 per day. Significant covariants on apparent clearance were identified as body weight, baseline C-reactive protein level and smoking habits. However, only body weight was found to be a significant covariant on apparent volume of distribution. In addition, golimumab concentrations in patients (50 mg golimumab every 4 weeks) not receiving MTX were $30 \%$ lower as compared with patients receiving MTX (Xu et al., 2009). So far, no possible explanation for the different effects of MTX on the serum golimumab concentrations has been provided (Xu et al., 2009).

A randomized, double-blind, placebo-controlled phase III multicenter study was conducted to evaluate the safety and efficacy of golimumab from week 0 to 20 in 405 patients with active PsA (Kavanaugh et al., 2009).

Active PsA was defined as at least three swollen joints and three tender joints as well as active plaque psoriasis with a qualifying lesion of at least $2 \mathrm{~cm}$ in diameter. Concomitant MTX, non-steroidal anti-inflammatory drugs (NSAIDs) and corticosteroids were permitted at stable doses.

A significant reduction in PASI 75 among patients receiving golimumab 50 or $100 \mathrm{mg}$ at week 14 (40 and 58\%) was observed when compared with patients receiving placebo (3\%). PASI 75 scores in patients with golimumab (50 and $100 \mathrm{mg}$ ) further improved at week 24 in both golimumab groups (56 and $66 \%$ ), whereas only $1 \%$ of patients in the placebo group reached a PASI 75 (Kavanaugh et al., 2009).

Golimumab significantly $(P<0.001)$ improved signs and symptoms of PsA compared with patients treated with placebo (Kavanaugh et al., 2009). An ACR 20 response at week 14 
could be achieved in $51 \%$ of patients treated with golimumab $50 \mathrm{mg}$ and in $45 \%$ of patients receiving golimumab $100 \mathrm{mg}$ versus only $9 \%$ in the placebo group. At week 24, an ACR 20 response was observed in 52\% in the golimumab 50-mg group and in $61 \%$ in the golimumab $100-\mathrm{mg}$ group versus $12 \%$ in the placebo group $(P<0.001)$. ACR 50 and 70 responses were also significantly higher in both golimumab groups than in the placebo group. At week 104, $91.4 \%$ of patients in the $50-\mathrm{mg}$ group and $73.1 \%$ in the $100-\mathrm{mg}$ group achieved an ACR 20 (Kavanaugh et al., 2009). A good or moderate DAS 28 response was significantly $(P<0.001)$ more often achieved in the golimumab 50 and 100-mg recipients than in the placebo group at week 14 (66 and 67\% vs. 24\%) and at week 24 (64 and 78\% vs. 24\%) (Kavanaugh et al., 2009). Assessment of physical function and health-related quality of life were measured by the Health Assessment Questionnaire (HAQ) and Short Form 36 Health Survey (SF-36) and significantly improved in both golimumab groups compared with the placebo group $(P<$ 0.001 for HAQ and SF-36 at all comparisons at week 24).Thus, in this study golimumab improved significantly the clinical signs and symptoms of PsA as well as the physical function and quality of life (Kavanaugh et al., 2009).

About the of safety of this treatment, Kavanaugh and coll. (Kavanaugh et al., 2009) reported that $8.6 \%$ of patients treated with golimumab shown a serious adverse event up to week 104: serious infectious adverse events comprised sepsis/cholecystitis and abscess formation. about the cancers registered: one basal cell carcinoma, one colon cancer and one small lung cell carcinoma in the golimumab 50-mg group. In the golimumab 100-mg group, three basal cell carcinomas, one prostate cancer and one small lung cancer occurred.

As for adverse events, infections of the upper respiratory tract and nasopharyngitis were most frequently reported.

\subsubsection{Certolizumab pegol (CDP870)}

Certolizumab pegol, a pegylated Fab-9 fragment of a humanized anti-TNF-a Moab, has been approved for the treatment of patients with CD (Bourne et al., 2008) and it has also been investigated in RA patients (Barnes \& Moots, 2007).

It binding to TNF- $\alpha$, blocks the interaction with specific receptors. Whereas adalimumab, etanercept and infliximab contain an IgG1 Fc region, which can induce antibody-dependent cell-mediated cytotoxicity (ADCC) and complement-dependent cytotoxicity (CDC), certolizumab lacking this Fc region, isn't able of inducing ADCC and CDC (European Medicines Agency [EMEA], 2008).

Pharmacokinetic analysis in the CDP870 trial showed a bioavailability of 85\% (EMEA, 2008). Peak plasma concentrations were attained between 54 and $171 \mathrm{~h}$ after subcutaneous injection. The mean serum concentration (Cmax) after the subcutaneous administration of 400 -mg certolizumab ranged from $46.3 \pm 13.1$ to $49.5 \pm 8.2 \mathrm{mg} \cdot \mathrm{mL}^{-1}$. An increase of Cmax and area under the curve (AUC) was observed with higher doses in a dose-proportional manner. The half-life of certolizumab was found to be approximately 14 days (EMEA, 2008)

Certolizumab pegol has been investigated in patients with moderate to severe psoriasis. In a phase II trial, patients were randomized to receive certolizumab pegol $200 \mathrm{mg}$, $400 \mathrm{mg}$ or placebo subcutaneously every 2 weeks up to week 12. At week 12, significantly more patients receiving certolizumab pegol 200 or $400 \mathrm{mg}$ achieved PASI 75 than in the placebo 
group (74.6 and $82.8 \%$ vs. $6.8 \%$ ) (Ortonne et al., 2007). The most frequently reported adverse events comprised headache, nasopharyngitis and pruritus. The frequency of adverse events was similar across all three groups. However, serious adverse events were more common in the $400-\mathrm{mg}$ group $(7.0 \%)$ than in the $200-\mathrm{mg}$ group $(3.3 \%)$ and in the placebo-group $(1.7 \%)$ (Ortonne et al., 2007). According to the data from the phase II study, PASI 75 results and side effects were comparable with those observed in patients treated with the approved TNF- $\alpha$ blockers adalimumab and infliximab. So far, no phase III studies or studies in patients with PsA have been conducted.

\subsection{T-cell modulators}

In 2003, alefacept and efalizumab were the first biological agents to be approved by the Food and Drug Administration (FDA) for the treatment of psoriasis (Pathirana et al., 2009). In the European Union, only efalizumab was approved for the psoriasis therapy (Pathirana et al., 2009). In 2009, efalizumab was withdrawn from the market in Europe and the United States (EMEA, 2009; Food and Drug Administration [FDA], 2009).

\subsubsection{Alefacept}

Alefacept, a recombinant dimeric fusion protein, is made up of the terminal portion of leukocyte function antigen-3 (LFA-3). It binds to extracellular human CD2 and the FC portion of human immunoglobulin IgG1 (Sugiyama et al., 2008). Alefacept blocks signalling between LFA-3 on antigen presenting cells and the CD2 molecule on T cells (primarily $\left.\mathrm{CD}^{2} 5 \mathrm{RO}^{+}\right)$.

Subsequently, the activation and proliferation of $\mathrm{CD}^{2} 5 \mathrm{RO}^{+} \mathrm{T}$ cells, which account for approximately $75 \%$ of $\mathrm{T}$ lymphocytes in psoriatic lesions, are inhibited. Furthermore, alefacept decreases the number of pathogenic T cells by binding CD2 on CD45RO+ $\mathrm{T}$ cells to the FcgIII receptor on natural killer cells, resulting in granzyme-mediated apoptosis of $\mathrm{T}$ cells (Gordon et al., 2003; Sobell et al., 2009; Sugiyama et al., 2008). Using a dosage of $15 \mathrm{mg}$ alefacept administered intramuscularly QW, PASI 75 scores at week 12 were found to range between 21 and 35\% (Gordon et al., 2003; Pathirana et al., 2009; Sugiyama et al., 2008). Recently, patients receiving alefacept in combination with MTX were shown to improve significantly in ACR 20 at week 24 compared with patients treated with MTX and placebo alone (54\% vs. $23 \%$; $P<0.001$ ) (Mease et al., 2006a).

\subsection{IL-12/IL-23 antagonists}

Briakinumab and ustekinumab are both IL-12/IL-23 antagonists. Whereas briakinumab is currently under investigation for the psoriasis treatment in several phase III studies, ustekinumab was recently approved by the EMEA for the therapy of chronic plaque psoriasis.

\subsubsection{Briakinumab (ABT874)}

Briakinumab is a recombinant fully human, IgG1 Moab targeting the shared p40 subunit of IL-12 and IL-23 (Kimball et al., 2008b). It binds to soluble forms of IL-12 and IL-23, leading to a decreased secretion of pro-inflammatory cytokines: IL-12, IL-6, IFN- $\gamma$ and TNF- $\alpha$, as shown in CD patients (Ding et al., 2008). 
In a phase I trial with 64 healthy controls, the pharmacokinetics of briakinumab (0.1-5.0 $\mathrm{mg} \mathrm{kg}^{-1}$ subcutaneously or intravenously) were evaluated. A linear relationship between the Cmax and AUC (concentration-time) was found with increasing doses. The terminal phase half-life time was about 9 days. No dose dependency was found for the volume distribution at steady state and the clearance of the drug. Subcutaneous and intramuscular application achieved an absolute bioavailability of 42 and 63\% respectively (Ding et al., 2008).

A phase II study with briakinumab was conducted (Kimball et al., 2008b) in patients with psoriasis. Patients were randomized in groups of 30 to receive either only one dose of briakinumab $200 \mathrm{mg}$ at week 0, $100 \mathrm{mg}$ briakinumab every other week for 12 weeks, $200 \mathrm{mg}$ weekly for 4 weeks, $200 \mathrm{mg}$ every other week for 12 weeks and $200 \mathrm{mg}$ every week for 12 weeks, or placebo respectively(Kimball et al., 2008b).

PASI 75 was significantly $(P<0.001)$ more often reached in patients in all five briakinumab treatment groups $(63,93,90,93$, and $90 \%$ respectively) compared with the placebo group (3\%). Statistically significant improvement to briakinumab therapy was rapid and could be registered in the briakinumab groups as early as at week 1 . During the 12-week period, improvement could be sustained in briakinumab-treated patients even for patients in the briakinumab $200 \mathrm{mg} \times 1$ and $200 \mathrm{mg} \times 4$ dosage groups.

Besides injection site reactions, other common side effects the trial study comprised nasopharyngitis and upper respiratory infections. In addition, non-infectious serious adverse events reported in this study included costal chondritis in one patient. Significantly more patients in the briakinumab groups (36\%) experienced adverse events compared with the placebo group (10\%) (Kimball et al., 2008b).

\subsubsection{Ustekinumab (CNTO1275)}

Ustekinumab is a human monoclonal antibody binding with high affinity to the p40 subunit of IL 12 and IL 23 and therefore inhibiting the binding to specific receptor (IL-12Rb1) expressed on various cells.

In a phase I study, patients with constant 70\% PASI improvement at weeks 8, 12 and 16 shown significant decreases in mRNA expression of different cytokines (IL-8, IL-18 and IFN- $\gamma$ ) as early as week $1(P<0.05)$, whereas, in patients without PASI improvement, no significant reduction of cytokine mRNA expression was observed(Wittig, 2007).

The pharmacokinetics of ustekinumab were assessed in different studies (A. B. Gottlieb et al., 2007; Kaufmann et al., 2004; Wittig, 2007): after a single subcutaneous injection, ustekinumab was slowly absorbed into the systemic circulation (mean Tmax about 12 days) and was afterwards slowly eliminated from the circulation (mean $\mathrm{t} 1 / 2$ around 20 days) (A. B. Gottlieb et al., 2007; Wittig, 2007).

The terminal half-life $(\mathrm{t} 1 / 2)$ was dose dependent and was found to range from $14.9 \pm 4.6$ days $\left(0.27 \mathrm{mg} \mathrm{kg}^{-1}\right.$ dose group) to $28.6 \pm 9.3$ days ( $2.7 \mathrm{mg} \mathrm{kg}^{-1}$ dose group) (A. B. Gottlieb et al., 2007). Similar results were also observed for $t 1 / 2$ by Kaufman (Kaufmann et al., 2004), ranging from $18.5 \pm 3.6$ in the $0.3-\mathrm{mg}$ group to $25.9 \pm 3.7$ in the 1.0-mg group. An increase of Cmax and AUC was observed with superior dosages (A. B. Gottlieb et al., 2007; Kaufmann et al., 2004). 
In the clinical trial conducted by Kaufman (Kaufmann et al., 2004), 18 psoriasis patients were enrolled in four dose groups: $0.1,0.3,1.0$ and $5.0 \mathrm{mg}$ per $\mathrm{kg}$ to assess the clinical response and the safety of a single intravenous administration of ustekinumab. At week 12, PASI 75 was reached in 25, 50, 60 and $100 \%$ of patients respectively. In patients responding to ustekinumab treatment, the expression of pro-inflammatory cytokines and chemokines IFN- $\gamma$, CXCL-8, CCR2, TNF- $\alpha$, IL-12p40 and IL-23p19 subunits was decreased, compared with baseline levels (Reddy et al., 2007; Toichi et al., 2006).

In a second double-blind, placebo-controlled study, patients were randomized to receive either a single subcutaneous injection of $0.27,0.675,1.35$ or $2.7 \mathrm{mg} \mathrm{kg-1}$ ustekinumab or placebo (A. B. Gottlieb et al., 2007). For a second time, patients treated with ustekinumab showed a dose-dependent improvement of their psoriasis. PASI 75 was achieved in $60 \%$ of the $0.27 \mathrm{mg} \mathrm{kg}^{-1}$ group, $100 \%$ in the $0.675 \mathrm{mg} \mathrm{kg}^{-1}$ group, $50 \%$ in the $1.35 \mathrm{mg} \mathrm{kg}^{-1}$ group and $100 \%$ in the $2.7 \mathrm{mg} \mathrm{kg}^{-1}$ group, but in none of the patients receiving placebo during the whole study period.

Krueger (G. G. Krueger et al., 2007) evaluated in a double-blind, placebo controlled trial, four subcutaneous dosing regimens of ustekinumab in patients with psoriasis; 320 patients were randomized to receive one of the following treatment regimens: one 45-mg dose, one 90-mg dose, four weekly 45-mg doses and four weekly 90-mg doses of ustekinumab or placebo. The primary endpoint of the study was a 75\% improvement in the PASI at week 12 . PASI 75 was achieved in 52\% of patients receiving ustekinumab $45 \mathrm{mg}$, in $59 \%$ receiving ustekinumab $90 \mathrm{mg}$, in $67 \%$ receiving four weekly $45-\mathrm{mg}$ doses and in $81 \%$ of patients receiving four weekly $90-\mathrm{mg}$ doses, whereas only $2 \%$ of patients in the placebo group achieved a PASI 75.

Another placebo-controlled double blind randomized crossover study was conducted to evaluate the efficacy of ustekinumab in 146 patients suffering from PsA (A. Gottlieb et al., 2009). Patients were either randomized to receive ustekinumab 90 or 63 mg every week for 4 weeks (weeks 0-3) followed by placebo at weeks 12 and 16 (76 patients, group 1) or placebo (weeks 0-3) and ustekinumab (63 mg) at weeks 12 and 16 (70 patients, group 2). ACR 20 at week 12 (taken as the primary endpoint of the study) was achieved by $42 \%$ of patients in group 1 and by $14 \%$ in group $2(P=0.0002)$. Significantly more patients in group 1 achieved PASI 75 compared with group 2 in week 12 (52\% vs. 5\%, $P<0.0001)$. However, one should note that the dosages of ustekinumab used in the study were higher (90 and $63 \mathrm{mg}$, respectively) than those recommended for patients of normal weight $(45 \mathrm{mg})$ with psoriasis (Leonardi et al., 2008).

In conclusion, we report the results of the two double-blind, placebo-controlled phase III studies (Phoenix 1 and Phoenix 2) in patients with psoriasis were performed parallel in USA and Europe. Primary outcome in both studies was PASI 75 at week 12 (Leonardi et al., 2008; 211,). 766 patients of Phoenix 1 trial were randomly assigned to receive either ustekinumab $45 \mathrm{mg}$ or $90 \mathrm{mg}$ at weeks 0 and 4 and afterwards every 12 weeks or placebo at weeks 0 and 4 and to cross over at week 12 to ustekinumab (Leonardi et al., 2008; Papp et al., 2008).

Furthermore, patients initially receiving ustekinumab and reaching a PASI 75 at weeks 28 and 40 were re-randomized at week 40 to either continue therapy with ustekinumab or to withdrawal of the study drug until loss of response. Significantly more patients in both ustekinumab groups (45 and $90 \mathrm{mg}$ ) received a PASI 75 at week 12 compared with the 
placebo group. Patients receiving maintenance therapy up to week 76 significantly better sustained PASI 75 than patients randomized to the drug withdrawal group $(P<0.0001)$.

The design of the Phoenix 2 study closely resembles that of the Phoenix 1 trial (Papp et al., 2008). Of the 1230 patients, 409 patients were randomized to receive ustekinumab $45 \mathrm{mg}$, 411 to receive ustekinumab $90 \mathrm{mg}$ and 410 to receive placebo at weeks 0 and 4 . The efficacy analysis at week 12 revealed the following results for the three groups. The primary endpoint was achieved in $66.7 \%$ of the ustekinumab 45 -mg group, $75.7 \%$ of the ustekinumab $90 \mathrm{mg}$ and $3.7 \%$ of the placebo group $(P<0.0001$ for both ustekinumab 45 and $90 \mathrm{mg}$ vs. placebo).

Quality of life was significantly improved in the patients treated with ustekinumab compared with the placebo groups $(P<0.0001)$ in both Phoenix trials. Patients randomized to maintenance therapy in the Phoenix 1 study were able to sustain improved DLQI scores until the end of the study, whereas in patients withdrawn from the study drug, the DLQI deteriorated again (Leonardi et al., 2008; Papp et al., 2008).

In a randomized active-controlled, parallel three-arm trial (ACCEPT trial), ustekinumab (45 and $90 \mathrm{mg}$, respectively) was compared versus the anti-TNF- $\alpha$ etanercept (50 mg twice weekly) (C. E. M. Griffiths et al., 2008). The primary endpoint of the study was PASI 75 at week 12. 903 patients were randomized in 3 treatment-arms as follows: 347 patients received etanercept $50 \mathrm{mg}$ subcutaneously twice weekly, 209 patients received ustekinumab $45 \mathrm{mg}$ subcutaneously at weeks 0 and 4 , and 347 patients received ustekinumab $90 \mathrm{mg}$ subcutaneously at weeks 0 and 4 . PASI 75 at week 12 was achieved by $56.8 \%$ of patients in the etanercept group, by $67.5 \%$ in the ustekinumab $45-\mathrm{mg}$ group and $73.8 \%$ in the ustekinumab 90-mg group. A greater proportion of patients receiving ustekinumab (45 or 90 mg) achieved PASI 75 when compared with the etanercept group $(P=0.012$ for ustekinumab $45 \mathrm{mg}, P<0.001$ for ustekinumab $90 \mathrm{mg}$ ). Interestingly, PASI 75 values at week 12 in patients receiving etanercept were better than those published in previous studies (Leonardi et al., 2008; Papp et al., 2008).

The table 4 resume the major results obtained using the briakinumab and ustekinumab in psoriasis treatments.

About the major side effects of treatments with ustekinumab; in the phase I studies, no serious adverse events were reported (A. B. Gottlieb et al., 2007; Kaufmann et al., 2004). Adverse events included headaches, abdominal pain and common cold symptoms. Adverse events were comparable in the phase II studies between ustekinumab and placebo groups (79\% vs. 72\%) (G. G. Krueger et al., 2007). Serious adverse events in patients treated with ustekinumab were infections (2 patients), myocardial infarctions (2 patients), a cerebrovascular accident ( 1 patient), non-melanoma skin cancer ( 2 patients) and prostate cancer (1 patient).

In the placebo group, one patient had a basal cell carcinoma and one patient experienced aggravation of his psoriasis requiring hospitalization. In the PsA trial conducted by Gottlieb, the following serious adverse events were reported in the ustekinumab groups: syncope (1 patient), respiratory tract infection (1 patient), haemorrhage (1 patient), stroke (1 patient), congestive heart failure/myocardial infarction/hypertension (1 patient), chest pain (1 
patient), gastric ulcer haemorrhage/abdominal pain/back pain (1 patient) and basal cell carcinoma (1 patient) respectively (A. Gottlieb et al., 2009). Two serious infections occurred during the placebo-controlled phase of the two large phase III trials: one case of cellulitis and one case of herpes zoster (both in the ustekinumab 90-mg group) (Ding et al., 2008; Ortonne et al., 2007).

During the placebo-controlled phase of the Phoenix 2 study, a squamous cell carcinoma in a patient in the placebo group and a basal cell carcinoma in a patient in the ustekinumab 90mg group were observed (Ding et al., 2008). Comparing patients on maintenance therapy with patients randomized to the withdrawal group in Phoenix 1 study did not reveal an increased infection rate between the two groups (Ortonne et al., 2007).

\begin{tabular}{|c|c|c|c|c|c|}
\hline Therapy & Disease & Trial Type & $\begin{array}{c}\text { Treatment }\left(\mathrm{n}^{\circ}\right. \\
\text { of patients) }\end{array}$ & $\begin{array}{l}\text { Major } \\
\text { Results }\end{array}$ & Reference \\
\hline Briakinumab & Psoriasis & $\begin{array}{l}\text { 12-week } \\
\text { RDBPC }\end{array}$ & $\begin{array}{l}\text { B } 200 \mathrm{mg} \text { x } 1(30) \\
\text { B } 100 \mathrm{mg} \text { eow (3) } \\
\text { B } 200 \mathrm{mg} \text { x } 4(30) \\
\text { B } 200 \mathrm{mg} \text { eow } \\
(30) \\
\text { B } 200 \mathrm{mg} \text { weekly } \\
(30) \\
\text { Placebo (30) }\end{array}$ & $\begin{array}{l}\text { PASI } 75 \text { at } \\
\text { week 12: } 63 \\
\text { PASI 75 at } \\
\text { week 12: } 93 \\
\text { PASI 75 at } \\
\text { week 12: } 90 \\
\text { PASI 75 at } \\
\text { week 12: } 93 \\
\text { PASI } 75 \text { at } \\
\text { week 12: } 90 \\
\text { PASI 75 at } \\
\text { week 12: } 1\end{array}$ & $\begin{array}{l}\text { Kimball et al., } \\
2008 \\
\text { Arch Dermatol } \\
\text { 144: 200-207. }\end{array}$ \\
\hline $\begin{array}{l}\text { Ustekinumab } \\
\text { PHOENIX } 1\end{array}$ & Psoriasis & RDBPC & $\begin{array}{l}\text { U } 45 \text { mg (255) } \\
\text { U } 90 \text { mg (256) } \\
\text { Placebo ( } 255\end{array}$ & $\begin{array}{l}\text { PASI } 75 \text { at } \\
\text { week 12: } 67.1 \\
\text { PASI } 75 \text { at } \\
\text { week 12: } 66.4 \\
\text { PASI } 75 \text { at } \\
\text { week } 12: 3.1\end{array}$ & $\begin{array}{l}\text { Leonardi et al., } \\
2008 \\
\text { Lancet 371: } \\
1665-1674 .\end{array}$ \\
\hline $\begin{array}{l}\text { Ustekinumab } \\
\text { PHOENIX } 2\end{array}$ & Psoriasis & RDBPC & $\begin{array}{l}\text { U } 45 \text { mg (409) } \\
\text { U } 90 \text { mg (411) } \\
\text { Placebo (410) }\end{array}$ & $\begin{array}{l}\text { PASI } 75 \text { at } \\
\text { week } 12: 66.7 \\
\text { PASI } 75 \text { at } \\
\text { week } 12: 75.7 \\
\text { PASI } 75 \text { at } \\
\text { week 12: } 3.7\end{array}$ & $\begin{array}{l}\text { Papp et al., } \\
2008 \\
\text { Lancet 371: } \\
1675-1684 .\end{array}$ \\
\hline $\begin{array}{l}\text { Ustekinumab } \\
\text { ACCEPT }\end{array}$ & Psoriasis & RDBPC & $\begin{array}{l}\text { U } 45 \mathrm{mg}(209) \\
\text { U } 90 \mathrm{mg}(347) \\
\text { E } 2 \text { X } 50 \mathrm{mg} \\
(347)\end{array}$ & $\begin{array}{l}\text { PASI } 75 \text { at } \\
\text { week } 12: 67.5 \\
\text { PASI } 75 \text { at } \\
\text { week } 12: 73.8 \\
\text { PASI } 75 \text { at } \\
\text { week } 12: 56.8\end{array}$ & $\begin{array}{l}\text { Griffiths et al., } \\
2010 \\
\text { N Engl J Med. } \\
\text { 362: 118-128 }\end{array}$ \\
\hline
\end{tabular}

$\mathrm{B}=$ Briakinumab; $\mathrm{E}=$ Etanercept $; \mathrm{U}=$ Ustekinumab; $\mathrm{RDBPC}=$ Randomized Double-Blind Placebo Controlled Trial

Table 4. Efficacy of anti- IL-12/IL-23 in the psoriasis cure 
However, as Th1 and Th17 blockade by ustekinumab might impair cell-mediated immunity, normal KCs host immunity and defence against malignancies, close monitoring in patients on long-term treatment with ustekinumab seems to be appropriate (O'Neill \& Kalb, 2009). In the ACCEPT trial, serious adverse events have been observed in $1.2 \%$ of patients in the etanercept group, $1.9 \%$ in the ustekinumab $45-\mathrm{mg}$ group and $1.2 \%$ of patients in the ustekinumab $90 \mathrm{mg}$ group respectively. These included 4 patients in each treatment group: etanercept group: abdominal pain, bacterial meningitis, nephrolithiasis, rotator cuff syndrome; 45-mg ustekinumab group: alcoholic pancreatitis, chest pain/hypertension, psychotic disorder, breast cancer; ustekinumab 90-mg group: urosepsis/renal failure, uveitis, appendicitis and gastroenteritis from food poisoning (C. E. M. Griffiths et al., 2008).

\section{Conclusion}

Based on a large series of studies, that we discuss in the different paragraphs, current evidence indicates the importance of $\mathrm{T}$ cells during psoriasis pathogenesis and demonstre that $\mathrm{T}$ cell expansion precedes the development of typical psoriatic changes; the more reasonable conclusion is that psoriasis is the outcome of an inappropriate $\mathrm{T}$ cell-based activation event, together with a defect in $\mathrm{KCs}$, whose combination results in the full psoriatic phenotype.

Once recognized the primary role of $\mathrm{T}$ cells in psoriasis pathogenesis, several biological therapies have been developed and proposed to counteract immune $\mathrm{T}$ response. These treatments consist in blocking the actions of several $\mathrm{T}$ cell cytokines that play a key role in sustain the pathogenesis of early and late events of psoriasis, e.g. anti-IL23 and anti-TNF- $\alpha$.

So far, considering published data from the clinical trials, the new biological agents have been shown to be efficient treatment options for patients suffering from psoriasis and the major comorbidities disease-associated, primarily PsA.

These new biological agents seem to have proven a good risk/benefit ratio. As psoriasis is considered a life-long disease and no causal therapy for the disease is yet available, longterm studies on safe and efficacious treatments are needed and are of major importance.

Taking into account the possibility that uncommon adverse events or events occurring during long-term exposure to these drugs might emerge in the future (e.g. the development of progressive multifocal leukoencephalopathy in long-term patients treated with efalizumab), vigilant and careful post-marketing surveillance in patients treated with biological agents is strongly recommended.

\section{Acknowledgment}

We thank Dr. Elena Niccolai for editorial support and Dr. Chiara Della Bella for the artworks. We wish to thank Istituto Superiore di Sanità, and Italian Ministry of University and Research for their support of our studies.

\section{References}

Abel, E. A., DiCicco, L. M., Orenberg, E. K., Fraki, J. E., \& Farber, E. M. (1986). Drugs in exacerbation of psoriasis. J Am Acad Dermatol, 15, 5 Pt 1, (Nov 1986), 1007-22. 
Abrams, J. R., Kelley, S. L., Hayes, E., Kikuchi, T., Brown, M. J., Kang, S., Lebwohl, M. G., Guzzo, C. A., Jegasothy, B. V., Linsley, P. S., \& Krueger, J. G. (2000). Blockade of T lymphocyte costimulation with cytotoxic $\mathrm{T}$ lymphocyte-associated antigen 4immunoglobulin (CTLA4Ig) reverses the cellular pathology of psoriatic plaques, including the activation of keratinocytes, dendritic cells, and endothelial cells. J Exp Med, 192, 5, (Sep 2000), 681-93, 0022-1007

Abrams, J. R., Lebwohl, M. G., Guzzo, C. A., Jegasothy, B. V., Goldfarb, M. T., Goffe, B. S., Menter, A., Lowe, N. J., Krueger, G., Brown, M. J., Weiner, R. S., Birkhofer, M. J., Warner, G. L., Berry, K. K., Linsley, P. S., Krueger, J. G., Ochs, H. D., Kelley, S. L., \& Kang, S. (1999), CTLA4 Igmediated blockade of T-cell costimulation in patients with psoriasis vulgaris. J Clin Invest, 103, 9, (May 1999), 1243-52, 0021-9738

Abu-Amer, Y., Erdmann, J., Alexopoulou, L., Kollias, G., Ross, F. P., \& Teitelbaum, S. L. (2000). Tumor necrosis factor receptors types 1 and 2 differentially regulate osteoclastogenesis. J Biol Chem, 275, 35, (Sep 2000), 27307-27310, 0021-9258

Alberti, K. G., Zimmet, P., \& Shaw, J. (2006). Metabolic syndrome - a new world wide definition. A Consensus Statement from the International Diabetes Federation. Diabet Med, 23, 5, (May 2006), 469-480, 1262-3636

Ali, Y., Tom, B. D. M., Schentag, C. T., Farewell, V. T., \& Gladman, D. D. (2007). Improved survival in psoriatic arthritis (PsA) with calendar time. Arthritis Rheum, 56, 8, (Aug 2007), 2708-2714, 0004-3591

Annacker, O., Asseman, C., Read, S., \& Powrie, F. (2003). Interleukin-10 in the regulation of T cell-induced colitis. J Autoimmun, 20, 4, (Jun 2003), 277-9

Antoni, C. E., Kavanaugh, A., van der Heijde, D., Beutler, A., Keenan, G., Zhou, B., Kirkham, B., Tutuncu, Z., Burmester, G. R., Schneider, U., Furst, D. E., Molitor, J., Keystone, E., Gladman, D. D., Manger, B., Wassenberg, S., Weier, R., Wallace, D. J., Weisman, M. H., Kalden, J. R., \& Smolen, J. S. (2008). Two-year efficacy and safety of infliximab treatment in patientswith active psoriatic arthritis: findings of the Infliximab MultinationalPsoriatic Arthritis Controlled Trial (IMPACT). J Rheumatol, 35, 5, (May 2008), 569-876, 0315-162X

Arican, O., Aral, M., Sasmaz, S., \& Ciragil, P. (2005). Serumlevels of TNFalpha, IFN-gamma, IL-6, IL-8, IL-12, IL-17, and IL-18 in patients with active psoriasis and correlation with disease severity. Mediators Inflamm , 2005, 5, (Oct 2005), 273-279,

Baadsgaard, O., Salvo, B., Mannie, A., Dass, B., Fox, D. A., \& Cooper, K. D. (1990). In vivo ultraviolet-exposed human epidermal cells activate $T$ suppressor cell pathways that involve CD4+CD45RA+ suppressor-inducer T cells. J Immunol, 145, 9, (Nov 1990), 2854-61, 0022-1767

Baker, B. S., Griffiths, C. E., Lambert, S., Powles, A. V., Leonard, J. N., Valdimarsson, H.,\& Fry, L. (1987), The effects of cyclosporin A on T lymphocyte and dendritic cell subpopulations in psoriasis. Br J Dermatol, 116, 4, (Apr 1987), 503-10, 0007-0963

Barnes, T., \& Moots, R. (2007). Targeting nanomedicines in the treatment of rheumatoid arthritis: focus on certolizumab pegol. Inter J Nanomed, 2, 1, (2007), 3-7, 1176-9114

Baron, R., \& Rawadi, G. (2007). Targeting the Wnt/BCatenin pathway to regulate bone formation in the adult skeleton. Endocrinology, 148, 6, (Jun 2007), 2635-2643, 00137227

Becker, K. G., Simon, R. M., Bailey-Wilson, J. E., Freidlin, B., Biddison, W. E., McFarland, H. F., \& Trent, J. M. (1998). Clustering of non-major histocompatibility complex 
susceptibility candidate loci in human autoimmune diseases. Proc Natl Acad Sci USA, 95, 17, (Aug 1998), 9979-9984, 0027-8424

Biedermann, T., Röcken, M., \& Carballido, J. M. (2004). TH1 and TH2 lymphocyte development and regulation of $\mathrm{TH}$ cell mediated immune responses of the skin. $J$ Invest Dermatol, 9, 1, (Jan 2004), 5-14, 0022-202X

Blauvelt, A. (2008). T-helper 17 cells in psoriatic plaques and additional genetic links between IL-23 and psoriasis. J Invest Dermatol, 128, 5, (May 2008), 1064-7, 0022-202X

Boker, A., Kimball, A. B., \& Rolz-Cruz, G. (2007). Biologicals in the treatment of psoriasis. Curr Opin Invest Drugs, 8, 11, (Nov 2007), 939-946, 1472-4472

Bonish, B., Jullien, D., Dutronc, Y., Huang, B. B., Modlin, R., Spada, F. M., Porcelli, S. A., \& Nickoloff, B. J. (2000). Overexpression of CD1d by keratinocytes in psoriasis and CD1d-dependent IFN-gamma production by NK-T cells. J Immunol, 165, 7, (Oct 2000), 4076-4085, 0022-1767

Bosani, M., Ardizzone, S., \& Porro, G. B. (2009). Biologic targeting in the treatment of inflammatory bowel diseases. Biologics, 3, (Jul 2009), 77-97, 1177-5475

Boulton, J. G., \& Bourne, J. T. (2007). Unstable diabetes in a patient receiving anti-TNF-alpha for rheumatoid arthritis. Rheumatology, 46, 1, (Jan 2007), 178-179, 1462-0324

Bourne, T., Fossati, G., \& Nesbitt, A. (2008). A PEGylated Fab' fragment against tumor necrosis factor for the treatment of Crohn's disease: exploring a new mechanism of action. BioDrugs 22, 5, (2008), 331-337, 1173-8804

Bovenschen, H. J., Gerritsen, W. J., van Rens, D. W., Seyger, M. M., de Jong, E. M., \& van de Kerkhof, P. C. (2007). Explorative immunohistochemical study to evaluate the addition of a topical corticosteroid in the early phase of alefacept treatment for psoriasis. Arch Dermatol Res, 298, 9, (Feb 2007), 457-463

Bowcock, A. M., \& Krueger, J. G. (2005). Getting under the skin: the immunogenetics of psoriasis. Nat Rev Immunol, 5, 9, (Sept 2005), 699-711, 1474-1733

Brandrup, F., Hauge, M., Henningsen, K., \& Eriksen, B. (1978). Psoriasis in an unselected series of twins. Arch Dermatol, 114, 6, (Jun 1978), 874-878, 0003-987X

Brewerton, D. A., Caffrey, M., Nicholls, A., Walters, D., \& James, D. C. (1974). HL-A 27 and arthropaties associated with ulcerative colitis and psoriasis. Lancet, 1, 7864, (May 1974), 956-958, 0140-6736

Cameron, A. L., Kirby, B., \& Griffiths, C. E. (2003). Circulating natural killer cells in psoriasis. Br J Dermatol, 149, 1, (Jun 2003), 160-164, 0007-0963

Cameron, A. L., Kirby, B., Fei, W., \& Griffiths, C. E. (2002). Natural killer and natural killer-T cells in psoriasis. Arch Dermatol Res, 294, 8, (Nov 2002), 363-369

Capon, F., Bijlmakers, M. J., Wolf, N., Quaranta, M., Huffmeier, U., Allen, M., Timms, K., Abkevich, V., Gutin, A., Smith, R., Warren, R. B., Young, H. S., Worthington, J., Burden, A. D., Griffiths, C. E., Hayday, A., Nestle, F. O., Reis, A., Lanchbury, J., Barker, J. N., \& Trembath, R. C. (2008). Identification of ZNF313/ RNF114 as a novel psoriasis susceptibility gene. Hum Mol Genet, 17, 13, (Jul 2008), 1938-45

Capon, F., Di Meglio, P., Szaub, J., Prescott, N. J., Dunster, C., Baumber, L., Timms, K., Gutin, A., Abkevic, V., Burden, A. D., Lanchbury, J., Barker, J. N., Trembath, R. C., \& Nestle, F. O. (2007). Sequence variants in the genes for the interleukin-23 receptor (IL23R) and its ligand (IL12B) confer protection against psoriasis. Hum Genet, 122, 2, (Sep 2007), 201-6

Chan, J. R., Blumenschein, W., Murphy, E., Diveu, C., Wiekowski, M., Abbondanzo, S., Lucian, L., Geissler, R., Brodie, S., Kimball, A. B., Gorman, D. M., Smith, K., de 
Waal Malefyt, R., Kastelein, R. A., McClanahan, T. K., \& Bowman, E. P. (2006). IL23 stimulates epidermal hyperplasia via TNF and IL-20R2-dependent mechanisms with implications for psoriasis pathogenesis. J Exp Med, 203, 12, (Nov 2006), 257787, 0022-1007

Chan, W. L., Pejnovic, N., Liew, T. V., Lee, C. A., Groves, R., \& Hamilton, H. (2003). NKT cell subsets in infection and inflammation. Immunol Lett, 85, 2, (Jan 2003), 159-163, 0165-2478

Clark, R. A., \& Kupper, T. S. (2006). Misbehaving macrophages in the pathogenesis of psoriasis. J Clin Invest 116, 8, (Aug 2006), 2084-7, 0021-9738

Cohen, A. D., Dreiher, J., \& Birkenfeld, S. (2009). Psoriasis associated with ulcerative colitis and Crohn's disease. J Eur Acad Dermatol Venereol, 23, 5, (May 2009), 561-565

Conrad, C., Boyman, O., Tonel, G., Tun-Kyi, A., Laggner, U., de Fougerolles, A., Kotelianski, V., Gardner, H., \& Nestle, F. O. (2007). Alpha1beta1 integrin is crucial for accumulation of epidermal T cells and the development of psoriasis. Nat Med, 13, 7, (Jun 2007), 836-42, 1078-8956

Curry, J. L., Qin, J. Z., Robinson, J., \& Nickoloff, B. J. (2003). Reactivity of resident immunocytes in normal and prepsoriatic skin using an ex vivo skin-explant model system. Arch Pathol Lab Med, 127, 3, (Mar 2003), 289-296, 0003-9985

Dahlqvist, S. R., Engstrand, S., Berglin, E., \& Johnson, O. (2004). Conversion towards an atherogenic lipid profile in rheumatoid arthritis patients during long-term infliximab therapy. Scand J Rheumatol, 35, 2, (Mar-Apr 2004), 107-111

De Filippis, L. G., Caliri, A., Lo Gullo, R., Bartolone, S. , Miceli, G., Cannavò, S. P., Borgia, F., Basile, G., Aloisi, G., Zimbaro, G., Scribano, E., \& Bagnato, G. F. (2005). Ultrasonography in the early diagnosis of psoriasis-associated enthesopathy. Int $J$ Tissue React, 27, 4 (2005), 159-162, 0250-0868

D'Elios, M. M., Del Prete, G., \& Amedei, A. (2010). Targeting IL-23 in human diseases. Expert Opin Ther Targets, 14, 7, (Jul 2010), 759-74, 1472-8222

Detmar, M., Brown, L. F., Claffey, K. P., Yeo, K. T., Kocher, O., Jackman, R. W.,. Berse, B., \& Dvorak, H. F. (1994). Overexpression of vascular permeability factor/vascular endothelial growth factor and its receptors in psoriasis. J Exp Med 180, 3, (Sep 1994), 1141-6, 0022-1007

Di Cesare, A., Di Meglio, P., \& Nestle, F. O. (2009). The IL-23/Th17 Axis in the Immunopathogenesis of Psoriasis. J Invest Dermatol, 129, 6, (Jun 2009), 1339-50, 0022-202X

Diarra, D., Stolina, M., Polzer, K., Zwerina, J., Ominsky, M. S., Dwyer, D., Korb, A., Smolen, J., Hoffmann, M., Scheinecker, C., van der Heide, D., Landewe, R., Lacey, D., Richards, W. G., \& Schett, G. (2007). Dickkopf-1 is a master regulator of joint remodeling. Nat Med, 13, 2, (Feb 2007), 156-163. 20, 1078-8956

Ding, C., Xu, J., \& Li, J. (2008). ABT-874, a fully human monoclonal anti IL-12/IL-23 antibody for the potential treatment of autoimmune diseases. Curr Opin Investig Drugs 9, 5, (May 2008), 515-522, 1472-4472

Djemadji-Oudjiel, N., Goerdt, S., Kodelja, V., Schmuth, M., \& Orfanos, C. E. (1996). Immunohistochemical identification of type II alternatively activated dendritic macrophages (RM 3/1+3, MS-1+/_, 25F9-) in psoriatic dermis. Arch Dermatol Res, 288, 12, (Nov 1996), 757-64

Duerr, R. H., Taylor, K. D., Brant, S. R., Rioux, J. D., Silverberg, M. S., Daly, M. J., Steinhart, A. H., Abraham, C., Regueiro, M., Griffiths, A., Dassopoulos, T., Bitton, A., Yang, 
H., Targan, S., Datta, L. W., Kistner, E. O., Schumm, L. P., Lee, A. T., Gregersen, P. K., Barmada, M. M., Rotter, J. I., Nicolae, D. L., \& Cho, J. H. (2006). A genome-wide association study identifies IL23R as an inflammatory bowel disease gene. Science, 314, 5804, (Dec 2006), 1461-1463, 0036-8075

Elder, J. T., Bruce, A. T., Gudjonsson, J. E., Johnston, A., Stuart, P. E., Tejasvi, T., Voorhees, J. J., Abecasis, G. R., \& Nair, R. P. (2010). Molecular dissection of psoriasis: integrating genetics and biology. J Invest Dermatol, 130, 5, (May 2010), 1213-26, 0022-202X

EMEA. (2008). Refusal assessment report for CIMZIA. Procedure No. EMEA/H/C/740. 19 March 2008, available from: <http://www.emea.europa.eu/humandocs/PDFs/EPAR/cimzia/H-740-RARen.pdf $>$

EMEA. (2009). European Medicines Agency recommends suspension of the marketing authorisation of Raptiva (efalizumab). 19 February 2009, available from: <http:// www.emea.europa.eu/humandocs/PDFs/EPAR/raptiva/20855709en.pdf >

Ettehadi, P., Greaves, M. W., Wallach, D., Aderka, D., \& Camp, R. D. (1994). Elevated tumor necrosis factor-alpha (TNF alpha) biological activity in psoriatic skin lesions. Clin Exp Immunol, 96, 1, (Apr 1994), 146-151, 0009-9104

Eyre, R. W., \& Krueger, G. G. (1984). The Koebner response in psoriasis, In: Psoriasis, Roenigk, H. H., Maibach, H. I., 105-116, Marcel Dekker, 0824772954, New York

Fan, X., Yang, S., Sun, L. D., Liang, Y. H., Gao, M., Zhang, K. Y., Huang, W., \& Zhang, X. (2007). Comparison of clinical features of HLA-Cw*0602-positive and-negative psoriasis patients in a Han Chinese population. Acta Derm Venereol, 87, 4, 335-40, 0001-5555

FDA. (2009). (2009). FDA statement on the voluntary withdrawal of raptiva from the US market. 8 April 2009, available from: <http://www.fda.gov/bbs/topics/NEWS/ 2009/NEW01992.html>

FitzGerald, O., \& Winchester, R. (2009). Psoriatic arthritis: from pathogenesis to therapy. Arthritis Res Ther, 11, 1, (Feb 2009), 214, 1478-6362

Fleischmajer, R., Kuroda, K., Hazan, R., Gordon, R. E., Lebwohl, M. G., Sapadin, A. N., Unda, F., Iehara, N., \& Yamada, Y. (2000). Basement membrane alterations in psoriasis are accompanied by epidermal overexpression of MMP-2 and its inhibitor TIMP-2. J Invest Dermatol, 115, 5, (Nov 2000), 771-7, 0022-202X

Fredriksson, T., \& Pettersson, U. (1978). Severe psoriasis - oral therapy with a new retinoid. Dermatologica,157, 4, (1978), 238-244, 0011-9059

Gallucci, S., Lolkema, M., \& Matzinger, P. (1999). Natural adjuvants: endogenous activators of dendritic cells. Nat Med, 5,11, (Nov 1999), 1249-55, 1078-8956

Gaspari, A. A. (2006). Innate and adaptive immunity and the pathophysiology of psoriasis. J Am Acad Dermatol, 54, 3, (Mar 2006), 67-80

Gelfand, J. M., Neimann, A. L., Shin, D. B., Wang, X., Margolis, D. J., \& Troxel, A. B. (2006). Risk of myocardial infarction in patients with psoriasis. JAMA, 296, 14, (Oct 2006), 1735-1741, 0098-7484

Gerdes, S., \& Mrowietz, U. (2009). Impact of comorbidities on the management of psoriasis. Curr Probl Dermatol, 38, (Jul 2009), 21-36

Gisondi, P., Girolomoni, G., Sampogna, F., Tabolli, S., \& Albeni, D. (2005). Prevalence of psoriatic arthritis and joints complaints in a large population of Italian patients hospitalized for psoriasis. Eur J Dermatol, 15, 4, (Jul-Aug 2005), 279-283, 1167-1122 
Gisondi, P., Tinazzi, I., El-Dalati, G., Gallo, M., Biasi, D., Barbara, L. M., \& Girolomoni, G. (2008). Lower limb enthesopathy in patients with psoriasis without clinical signs of arthropaty: a hospital-based case-control study. Ann Rheum Dis, 67, 1, (Jan 2008), 26-30, 0003-4967

Gladman, D. D. (2009). Psoriatic arthritis. Dermatol Ther, 22, 1, (Jan-Feb 2009), 40-55, 13960296

Gladman, D. D., Farewell, V. T., Husted, J., \& Wong, K. (1998). Mortality studies in psoriatic arthritis. Results from a single centre. II. Prognostic indicators for mortality. Arthritis Rheum, 41, 6, (Jun 1998), 1103-1110, 0004-3591

Gladman, D. D., Stafford-Brady, F., Chang, C. H., Lewandowski, K., \& Russell, M. L. (1990). Longitudinal study of clinical and radiological progression in psoriatic arthritis. $J$ Rheumatol, 17, 6, (Jun 1990), 809-812, 0315-162X

Gondek, D. C., Lu, L. F., Quezada, S. A., Sakaguchi, S., \& Noelle, R. J. (2005). Cutting edge: contact-mediated suppression by $\mathrm{CD} 4+\mathrm{CD} 25+$ regulatory cells involves a granzyme B-dependent, perforin-independent mechanism. J Immunol, 174, 4, (Feb 2005), 1783-6, 0022-1767

Gordon, K. B., Vaishnaw, A. K., O'Gorman, J., Haney, J., Menter, A., \& Alefacept Clinical Study Group. (2003). Treatment of psoriasis with alefacept: correlation of clinical improvement with reductions of memory T cell counts. Arch Dermatol 139, 12, (Dec 2003), 1563-1570, 0003-987X

Gottlieb, A. B., Chamian, F., Masud, S., Cardinale, I., Abello, M. V., Lowes, M. A., Chen, F., Magliocco, M., \& Krueger, J. G. (2005). TNF inhibition rapidly down-regulates multiple proinflammatory pathways in psoriasis plaques. J Immunol, 175, 4, (Aug 2005), 2721-9, 0022-1767

Gottlieb, A. B., Cooper, K. D., McCormick, T. S., Toichi, E., Everitt, D. E., Frederick, B., Zhu, Y., Pendley, C. E., Graham, M. A., \& Mascelli, M. A. (2007). A phase 1, doubleblind, placebo-controlled study evaluating single subcutaneous administration of human interleukin-12/23 monoclonal antibody in subjects with plaque psoriasis. Curr Med Res Opin, 23, 5, (May 2007), 1081-1092

Gottlieb, A. B., Mease, P. J., Mark Jackson, J., Eisen, D., Amy Xia, H., Asare, C., \& Stevens, S. R. (2006). Clinical characteristics of psoriatic arthritis and psoriasis in dermatologists' office. J Dermatolog Treat, 17, 5, (2006), 279-287

Gottlieb, A., Menter, A., Mendelsohn, A., Shen, Y. K., Li, S., Guzzo, C., Fretzin, S., Kunynetz, R., Kavanaugh, A. (2009). Ustekinumab, a human interleukin 12/23 monoclonal antibody, for psoriatic arthritis: randomised, double-blind, placebocontrolled, crossover trial. Lancet, 373, 9664, (Feb 2009), 633-40, 0140-6736

Gottlieb, S. L., Gilleaudeau, P., Johnson, R., Estes, L., Woodworth, T. G., Gottlieb, A. B., \& Krueger, J. G. (1995). Response of psoriasis to a lymphocyte-selective toxin (DAB389IL-2) suggests a primary immune, but not keratinocyte, pathogenic basis. Nat Med, 1, 5, (May 1995), 442-7, 1078-8956

Griffiths, C. E. M., Strober, B., van de Kerkhof, P. C. M., Ho, V., Guzzo, C., Yeilding, N. (2008). A phase 3 multicenter, randomized study comparing ustekinumab and etanercept for the treatment of moderate to severe plaque psoriasis. Proceedings of European Academy of Dermatology and Venerology Annual Congress Paris, July 2008.

Griffiths, C. E., \& Barker, J. N. (2007). Pathogenesis and clinical features of psoriasis. Lancet, 370, 9583, (Jul 2007), 263-271, 0140-6736 
Griffiths, C. E., Christophers, E., Barker, J. N., Chalmers, R. J., Chimenti, S., Krueger, G. G., Leonardi, C., Menter, A., Ortonne, J. P., \& Fry, L. (2007). A classification of psoriasis vulgaris according to phenotype. Br J Dermatol, G, 2, (Feb 2007), 258-262, 0007-0963

Grundy, S. M., Cleeman, J. I., Daniels, S. R., Donato, K. A., Eckel, R. H., Franklin, B. A., Gordon, D. J., Krauss, R. M., Savage, P. J., Smith. S. C. Jr., Spertus, J. A., Costa, F., American Heart Association, \& National Heart, Lung, and Blood Institute. (2005). Diagnosis and management of the metabolic syndrome: an American Heart Association/National Heart, Lung, and Blood Institute Scientific Statement. Circulation, 112, 17, (Oct 2005), 2735-2752, 0009-7322

Gudjonsson, J. E., Johnston, A., Sigmundsdottir, H., \& Valdimarsson, H. (2004). Immunopathogenic mechanisms in psoriasis. Clin Exp Immunol, 135, 1, (Jan 2004), $1-8,0009-9104$

Gudjonsson, J. E., Karason, A., Runarsdottir, E. H., Antonsdottir, A. A., Hauksson, V. B., Jonsson, H. H., Gulcher, J., Stefansson, K., \& Valdimarsson, H. (2006). Distinct clinical differences between HLA-Cw*0602 positive and negative psoriasis patients-an analysis of 1019 HLA-C- and HLA-B-typed patients. J Invest Dermatol, 126, 4, (Apr 2006), 740-5, 0022-202X

Gupta, M. A., Gupta, A. K., Kirkby, S., Schork, N. J., Gorr, S. K., Ellis, C. N., \& Voorhees, J. J. (1989). A psychocutaneous profile of psoriasis patients who are stress reactors. A study of 127 patients. Gen Hosp Psychiatry, 11, 3, (May 1989), 166-73

Haider, A. S., Duculan, J., Whynot, J. A., \& Krueger, J. G. (2006). Increased JunB mRNA and protein expression in psoriasis vulgaris lesions. J Invest Dermatol, 126, 4, (Apr 2006), 912-4, 0022-202X

Haider, A. S., Lowes, M. A., Suárez-Farinas, M., Zaba, L. C., Cardinale, I., Khatcherian, A., Novitskaya, I., Wittkowski, K. M., \& Krueger, J. G. (2008). Identification of cellular pathways of "type 1," Th17 T cells, and TNF- and inducible nitric oxide synthaseproducing dendritic cells in autoimmune inflammation through pharmacogenomic study of cyclosporine A in psoriasis. J Immunol, 180, 3, (Feb 2008), 1913-20, 0022-1767

Henseler, T., \& Christophers, E. (1985). Psoriasis of early and late onset: characterization of two types of psoriasis vulgaris. J Am Acad Dermatol, 13, 3, (Sept 1985), 450-6

Henseler, T., \& Christophers, E. (1995). Disease concomitance in psoriasis. J Am Acad Dermatol, 32, 6, (Jun 1995), 982-986

Hensen, P., Windemuth, C., Hüffmeier, U., Rüschendorf, F., Stadelmann, A., Hoppe, V., Fenneker, D., Ständer, M., Schmitt-Egenolf, M., Wienker, T. F., Traupe, H., \& Reis, A. (2003). Association scan of the novel psoriasis susceptibility region on chromosome 19: evidence for both susceptible and protective loci. Exp Dermatol, 12,4, (Aug 2003), 490-6

Holash, J., Maisonpierre, P. C., Compton, D., Boland, P., Alexander, C. R., Zagzag, D., Yancopoulos, G. D., \& Wiegand, S. J. (1999). Vessel cooption, regression, and growth in tumors mediated by angiopoietins and VEGF. Science, 284, 5422, (Jun 1999), 1994-8, 0036-8075

Hüffmaier, U., Lascorz, J., Böhm, B., Lohmann, J., Wendler, J., Mössner, R., Reich, K., Traupe, H., Kurrat, W., Burkhardt, H., \& Reis, A. (2009). Genetic variants of the IL23R pathway: association with psoriatic arthritis and psoriasis vulgaris, but no specific risk factor for arthritis. J Invest Dermatol, 129, 2, (Feb 2009), 355-358, 0022$202 X$ 
Huvers, F. C., Popa, C., Netea, M. G., van den Hoogen, F. H., \& Tack, C. J. (2007). Improved insulin sensitivity by anti-TNFalpha antibody treatment in patients with rheumatic diseases. Ann Rheum Dis, 66, 4, (Apr 2007), 558-559, 0003-4967

Irace, C. ,Mancuso, G., Fiaschi, E., Madia, A., Sesti, G., \& Gnasso, A. (2004). Effect of anti TNFalpha therapy on arterial diameter and wall shear stress and HDL cholesterol. Atherosclerosis, 177, 1, (Nov 2004), 113-118, 0021-9150

Jablonska, S. (1986). Immunological mechanisms in psoriasis: role of polymorphonuclear leukocytes, In: Psoriasis, Farber, E. M., Nall, L., Morhenn, V., \& Jacobs, P. H., 131-7, Elsevier, 0444012125, New York

Jegasothy, B. V., Ackerman, C. D., Todo, S., Fung, J. J., Abu-Elmagd, K., \& Starzl, T. E. (1992). Tacrolimus (FK 506)-a new therapeutic agent for severe recalcitrant psoriasis. Arch Dermatol, 128, 6, (Jun 1992), 781-5, 0003-987X

Johnson, L. W., \& Weinstock, R. S. (2006). The metabolic syndrome: concepts and controversy. Mayo Clin Proc, 81, 12, (Dec 2006), 1615-1620, 0025-6196

Kana, D., Stafford, L., Bresniham, B., \& Fitzgerald, O. (2003). A prospective, clinical and radiological study of early psoriatic arthritis: an early synovitis clinic experience. Rheumatology, 42, 12, (Dec 2003), 1460-1468, 1462-0324

Katz, H. I., Waalen, J., \& Leach, E. E. (1994). Acitretin in psoriasis: an overview of adverse effects. J Am Acad Dermatol, 41, 3 Pt 2, (Sep 1994), S7-S12

Kauffman, C. L., Aria, N., Toichi, E., McCormick, T. S., Cooper, K. D., Gottlieb, A. B., Everitt, D. E., Frederick, B., Zhu, Y., Graham, M. A., Pendley, C. E., \& Mascelli, M. A. (2004). A phase I study evaluating the safety, pharmacokinetics, and clinical response of a human IL-12 p40 antibody in subjects with plaque psoriasis. J Invest Dermatol, 123, 6, (Dec 2004), 1037-44, 0022-202X

Kavanaugh, A., McInnes, I., Mease, P., Krueger, G. G., Gladman, D., Gomez- Reino, J. Papp, K., Zrubek, J., Mudivarthy, S., Mack, M., Visvanathan, S., \& Beutler, A. (2009). Golimumab, a new human tumor necrosis factor a, administered every four weeks as a subcutaneous injection in psoriatic arthritis: twenty-four-week efficacy and safety results of a randomized, placebo-controlled study. Arthritis Rheum, 60, 4, (Apr 2009), 976- 986, 0003-4967

Keffer, J., Probert, L., Cazlaris, H., Georgopoulos, S., Kaslaris, E., Kioussis, D., \& Kollias, G. (1991). Transgenic mice expression human tumor necrosis factor: a predictive genetic model of arthritis. EMBO J, 10, 13 (Dec 1991), 4025-4031

Kimball, A. B., Gladman, D., Gelfand, J.M., Gordon, K., Horn, E. J., Korman, N. J., Korver, G., Krueger, G. G., Strober, B. E., Lebwohl, M. G., \& National Psoriasis Foundation. (2008a). National Psoriasis Foundation clinical consensus on psoriasis comorbidities and recommendations for screening. J Am Acad Dermatol, 58, 6, (Jun 2008), 1031-1042

Kimball, A. B., Gordon, K. B., Langley, R. G., Menter, A., Chartash, E. K., \& Valdes, J. (2008b). Safety and efficacy of ABT-874, a fully human interleukin 12/23 monoclonal antibody, in the treatment of moderate to severe chronic plaque psoriasis: results of a randomized, placebo-controlled, phase 2 trial. Arch Dermatol, 144, 2, (Feb 2008), 200-7, 0003-987X

Kimball, A. B., Robinson, D. Jr., Wu, Y., Yeilding, N., Paramore, C., Fraeman, K., \& Bala, M. (2008c). Cardiovascular disease and risk factors among psoriasis patients in two US healthcare databases, 2001-2002. Dermatology, 217, 1, (Mar 2008), 27-37, 1018-8665 
Koreck, A., Sura'nyi, A., Szo“ny, B. J., Farkas, A., Bata-Csörgö, Z., Kemény, L., \& Dobozy, A. (2002). CD3+CD56+ NK T cells are significantly decreased in the peripheral blood of patients with psoriasis. Clin Exp Immunol, 127, 1, (Jan 2002), 176-182, 0009-9104

Kremers, H. M., McEvoy, M. T., Dann, F. J., \& Gabriel, S. E. (2007). Heart disease in psoriasis. J Am Acad Dermatol, 57, 2, (Aug 2007), 347-354

Krueger, G. G., Bergstresser, P. R., Lowe, N. J., Voorhees, J. J., \& Weinstein, G. D. Psoriasis. (1984). J Am Acad Dermatol, 11, 5, (Nov 1984), 937-47

Krueger, G. G., Langley, R. G., Leonardi, C., Yeilding, N., Guzzo, C., Wang, Y., Dooley, L. T., Lebwohl, M., \& CNTO 1275 Psoriasis Study Group. (2007). A human interleukin12/23 monoclonal antibody for the treatment of psoriasis. N Engl J Med, 356, 6, (Feb 2007), 580-92, 0028-4793

Krueger, J. G. (2002). The immunologic basis for the treatment of psoriasis with new biologic agents. J Am Acad Dermatol, 46, 1, (Jan 2002), 1-23

Kuroda, K., Sapadin, A., Shoji, T., Fleischmajer, R., \& Lebwohl, M. (2001). Altered expression of angiopoietins and Tie2 endothelium receptor in psoriasis. J Invest Dermatol, 116, 15, (May 2001), 713-20, 0022-202X

Langewouters, A. M., van Erp, P. E., de Jong, E. M., \& van de Kerkhof, P. C. (2008). Lymphocyte subsets in peripheral blood of patients with moderate-tosevere versus mild plaque psoriasis. Arch Dermatol Res 2008; 300, 3, (Mar 2008), 107-113

Langrish, C. L., Chen, Y., Blumenschein, W. M., Mattson, J., Basham, B., Sedgwick, J. D., McClanahan, T., Kastelein, R. A., \& Cua, D. J. (2005). IL-23 drives a pathogenic T cell population that induces autoimmune inflammation. J Exp Med, 201, 2, (Jan 2005), 233-40, 0022-1007

Larsen, R., Ryder, L. P., Svejgaard, A., \& Gniadecki, R. (2007). Changes in circulating lymphocyte subpopulations following administration of the leucocyte functionassociated antigen-3 (LFA-3)/IgG1 fusion protein alefacept. Clin Exp Immunol, 149, 1, (Jun 2007), 23-30

Leonardi, C. L., Kimball, A. B., Papp, K. A., Yeilding, N., Guzzo, C., Wang, Y., Li, S., Dooley, L. T., Gordon, K. B., \& PHOENIX 1 study investigators. (2008). Efficacy and safety of ustekinumab, a human interleukin-12/23 monoclonal antibody, in patients with psoriasis: 76-week results from a randomised, double-blind, placebo-controlled trial (PHOENIX 1). Lancet, 371, 9625, (May 2008), 1665-74, 0140-6736

Lew, W., Bowcock, A. M., \& Krueger, J. G. (2004). Psoriasis vulgaris: cutaneous lymphoid tissue supports T-cell activation and "Type 1" inflammatory gene expression. Trends Immunol, 25, 6, (Jun 2004), 295-305, 1471-4906

Liao, Y. H., Jee, S. H., Sheu, B. C., Huang, Y. L., Tseng, M. P., Hsu, S. M., \& Tsai, T. F. (2006). Increased expression of the natural killer cell inhibitory receptor CD94/NKG2A and $\mathrm{CD} 158 \mathrm{~b}$ on circulating and lesional $\mathrm{T}$ cells in patients with chronic plaque psoriasis. Br J Dermatol, 155, 2, (Aug 2006), 318-324, 0007-0963

Lima, X. T., Seidler, E. M., Lima, H. C., \& Kimball, A. B. (2009). Long-term safety of biologics in dermatology. Dermatol Ther, 22, 1, (Jan-Feb 2009), 2-21, 1396-0296

Mallbris, L., Akre, O., Granath, F., Yin, L., Lindelöf, B., Ekbom, A., \& Ståhle-Bäckdahl, M. (2004). Increased risk for cardiovascular mortality in psoriasis inpatients but not in outpatients. Eur J Epidemiol, 19, 3, (2004), 225-230

Mallon, E., Newson, R., \& Bunker, C. B. (1999). HLA-Cw6 and the genetic predisposition to psoriasis: a metaanalysis of published serologic studies. J Invest Dermatol, 113, 4, (Oct 1999), 693-5, 0022-202X 
Marble, D. J., Gordon, K. B., Nickoloff, B. J. (2007). Targeting TNFalpha rapidly reduces density of dendritic cells and macrophages in psoriatic plaques with restoration of epidermal keratinocyte differentiation. J Dermatol Sci, 48, 2, (Nov 20079, 87-101, 0923-1811

Marra, M., Campanati, A., Testa, R., Sirolla, C., Bonfigli, A. R., Franceschi, C., Marchegiani, F., \& Offidani, A. (2007). Effect of etanercept on insulin sensitivity in nine patients with psoriasis. Int J Immunopathol Pharmacol, 20, 4, (Oct-Dec 2007), 731-736

Martin, M. P., Nelson, G., Lee, J. H., Pellett, F., Gao, X., Wade, J., Wilson, M. J., Trowsdale, J., Gladman, D., \& Carrington, M. (2002). Cutting edge: susceptibility to psoriatic arthritis: influence of activating killer Ig-like receptor genes in the absence of specific HLA-C alleles. J Immunol, 169, 6, (Sept 2002), 2818-22, 0022-1767

McEwen, C., DiTata, D., Lingg, C., Porini, A., Good, A., \& Rankin, T. (1971). Ankylosing spondylitis and spondylitis accompanying ulcerative colitis, regional enteritis, psoriasis and Reiter's disease. A comparative study. Arthritis Rheum, 14, 3, (MayJun 1971), 291-318, 0004-3591

McKenzie, B. S., Kastelein, R. A., \& Cua, D. J. (2006). Understanding the IL-23-IL-17 immune pathway. Trends Immunol, 27, 1, (Jan 2006), 17-23, 1471-4906

Mease, P. J., Gladman, D. D., \& Keystone, E. C. (2006a). Alefacept with methotrexate for the treatment of psoriatic arthritis: results from a double blind, placebo-controlled study. Arthritis Rheum 54, 5, (May 2006), 1638- 1645, 0004-3591

Mease, P. J., Kivitz, A. J., Burch, F. X., Siegel, E. L., Cohen, S. B., Ory, P., Salonen, D., Rubenstein, J., Sharp, J. T., Dunn, M., \& Tsuji, W. (2006b). Continued inhibition of radiographic progression in patients with psoriatic arthritis following 2 years of treatment with etanercept. J Rheumatol, 33, 4, (Apr 2006), 712-721, 0315-162X

Menssen, A., Trommler, P., Vollmer, S., Schendel, D., Albert, E., Gurtler, L., Riethmüller, G., \& Prinz, J. C. (1995). Evidence for an antigenspecific cellular immune response in skin lesions of patients with psoriasis vulgaris. J Immunol, 155, 8, (Oct 1995), 407883, 0022-1767

Menter, A., Gottlieb, A., Feldman, S. R., Van Voorhees, A. S., Leonardi, C. L., Gordon, K. B., Lebwohl, M. G., Koo, J. Y., Elmets, C. A., Korman, N. J., Beutner, K. R., \& Bhushan, R. (2008). Guidelines of care for the management of psoriasis and psoriatic arthritis: section I. Overview of psoriasis and guidelines of care for the treatment of psoriasis with biologics. J Am Acad Dermatol, 58, 5, (May 2008), 826-850

Montecucco, C. (2006). Remission, a therapeutic goal in inflammatory arthropathies? Clinical data from adalimumab studies. Drugs, 66, 14, (2006), 1783-1795, 0012-6667

Morris, A., Rogers, M., Fischer, G., \& Williams, K. (2001). Childhood psoriasis: a clinical review of 1262 cases. Pediatr Dermatol, 18, 3, (May-Jun 2001), 188-98

Mössner, R., Schön, M. P., \& Reich, K. (2008). Tumor necrosis factor antagonists in the therapy of psoriasis. Clin Dermatol 26, 5, (Sep-Oct 2008), 486-502, 0738-081X

Mrowietz, U., Elder, J. T., \& Barker, J. (2006). The importance of disease associations and concomitant therapy for the long-term management of psoriasis patients. Arch Dermatol Res, 298, 7, (Dec 2006), 309-319

Nair, R. P., Stuart, P. E., Nistor, I., Hiremagalore, R., Chia, N. V., Jenisch, S., Weichenthal, M., Abecasis, G. R., Lim, H. W., Christophers, E., Voorhees, J. J., \& Elder, J. T. (2006). Sequence and haplotype analysis supports HLA-C as the psoriasis susceptibility 1 gene. Am J Hum Genet, 78, 5, (May 2006), 827-51, 0002-9297 
Najarian, D. J., \& Gottlieb, A. B. (2003). Connections between psoriasis and Crohn's disease. J Am Acad Dermatol, 48, 6, (Jun 2003), 805-821

Nakamura, K., Kitani, A., Fuss, I., Pedersen, A., Harada, N., Nawata, H., \& Strober, W. (2004). TGF-beta 1 plays an important role in the mechanism of CD4+CD25+ regulatory $\mathrm{T}$ cell activity in both humans and mice. J Immunol, 172, 2, (Jan 2004), 834-42, 0022-1767

Namazi, M. R. (2004). Paradoxical exacerbation of psoriasis in AIDS: proposed explanations including the potential roles of substance $\mathrm{P}$ and gram-negative bacteria. Autoimmunity, 37, 1, (Feb 2004), 67-71

Neimann, A. L., Shin, D. B., Wang, X., Margolis, D. J., Troxel, A. B., \& Gelfand, J. M. (2006). Prevalence of cardiovascular risk factors in patients with psoriasis. J Am Acad Dermatol 55, 5, (Nov 2006), 829-835

Nestle, F. O., Kaplan, D. H., \& Barker, J. (2009). Psoriasis. N Engl J Med, 361, 5, (Jul 2009), 496-509, 0028-4793

Nickoloff, B. J. (1999a). Skin innate immune system in psoriasis: friend or foe?. J Clin Invest, 104, 9, (Nov 1999), 1161-4, 0021-9738

Nickoloff, B. J., \& Nestle, F. O. (2004). Recent insights into the immunopathogenesis of psoriasis provide new therapeutic opportunities. J Clin Invest, 113, 12, (Jun 2004), 1664-1675, 0021-9738

Nickoloff, B. J., Bonish, B., Huang, B. B., \& Porcelli, S. A. (2000). Characterization of a T cell line bearing natural killer receptors and capable of creating psoriasis in a SCID mouse model system. J Dermatol Sci, 24, 3, (Dec 2000), 212-225, 0923-1811

Nickoloff, B. J., Karabin, G. D., Barker, J. N., Griffiths, C. E., Sarma, V., Mitra, R. S., Elder, J. T., Kunkel, S. L., \& Dixit, V. M. (1991). Cellular localization of interleukin-8 and its inducer, tumor necrosis factor-alpha in psoriasis. Am J Pathol, 138, 1, (Jan 1991), 129-40, 0002-9440

Nickoloff, B. J., Qin, J. Z., \& Nestle, F. O. (2007a). Immunopathogenesis of psoriasis. Clinic Rev Allerg Immunol, 33, 1-2, (Oct 2007), 45-56, 1080-0549

Nickoloff, B. J., Wrone-Smith, T., Bonish, B., \& Porcelli, S. A. (1999b). Response of murine and normal human skin to injection of allogeneic blood-derived psoriatic immunocytes. Detection of T cells expressing receptors typically present on natural killer cells, including CD94, CD158, and CD161. Arch Dermatol, 135, 5, (May 1999), 546-552, 0003-987X

Nickoloff, B. J., Xin, H., Nestle, F. O., \& Qin, J. Z. (2007b). The cytokine and chemokine network in psoriasis. Clin Dermatol 25, 6, (Nov-Dec 2007), 568-573, 0738-081X

Nograles, K. E., Brasington, R.D., \& Bowcock, A. M. (2009). New insights into the pathogenesis and genetics of psoriatic arthritis. Nat Clin Pract Rheumatol, 5, 2, (Feb 2009), 83-91, 1745-8382

O'Neill, J. L., \& Kalb, R. E. (2009). Ustekinumab in the therapy of chronic plaque psoriasis. Biologics 3, (Jul 2009), 159-168, 1177-5475

Oppmann, B., Lesley, R., Blom, B., Timans, J. C., Xu, Y., Hunte, B., Vega, F., Yu, N., Wang, J., Singh, K., Zonin, F., Vaisberg, E., Churakova, T., Liu, M., Gorman, D., Wagner, J., Zurawski, S., Liu, Y., Abrams, J. S., Moore, K. W., Rennick, D., de Waal-Malefyt, R., Hannum, C., Bazan, J. F., \& Kastelein, R. A. (2000). Novel p19 protein engages IL12 p40 to form a cytokine, IL-23, with biological activities similar as well as distinct from IL-12. Immunity, 13, 5, (Nov 2000), 715-25, 1074-7613 
Ortonne, J. P., Tassel, C., \& Reich, K. (2007). Efficacy of certolizumab pegol, a PEGylated $\mathrm{Fab}^{\prime}$ fragment of an anti-TNF-a monoclonal antibody, in patients previously exposed to biologicals. Preliminary results of a randomised, placebo-controlled phase II clinical trial in psoriasis, Proceedings of the 16th Congress of the European Academy of dermatology and Venerology, Vienna, Austria, May 2007.

Ozcakar, L., Cetin, A., Inanici, F., Kaymal, B., Gurer, C. K., \& Kolemen, F. (2005). Ultrasonographical evaluation of the Achilles' tendon in psoriasis patients. Int $J$ Dermatol, 44, 11, (Nov 2005), 930-932, 0011-9059

Papp, K. A., Langley, R. G., Lebwohl, M., Krueger, G. G., Szapary, P., Yeilding, N., Guzzo, C., Hsu, M. C., Wang, Y., Li, S., Dooley, L. T., Reich, K., PHOENIX 2 study investigators. (2008). Efficacy and safety of ustekinumab, a human interleukin12/23 monoclonal antibody, in patients with psoriasis: 52-week results from a randomised, double-blind, placebo-controlled trial (PHOENIX 2). Lancet, 371, 9625, (May 2008), 1675-84, 0140-6736

Pathirana, A., Ormerod, A. D., Saiag, P., Smith, C., Spuls, P. I., Nast, A., Barker, J., Bos, J. D., Burmester, G. R., Chimenti, S., Dubertret, L., Eberlein, B., Erdmann, R., Ferguson, J., Girolomoni, G., Gisondi, P., Giunta, A., Griffiths, C., Hönigsmann, H., Hussain, M., Jobling, R., Karvonen, S. L., Kemeny, L., Kopp, I., Leonardi, C., Maccarone, M., Menter, A., Mrowietz, U., Naldi, L., Nijsten, T., Ortonne, J. P., Orzechowski, H. D., Rantanen, T., Reich, K., Reytan, N., Richards, H., Thio, H. B., van de Kerkhof, P., \& Rzany, B. (2009). European S3-Guidelines on the systemic treatment of psoriasis vulgaris. J Eur Acad Dermatol Venerol, 23, 2, (Oct 2009), 1-70

Pisani, M., \& Ruocco, V. (1984). 'Twin' psoriasis in monozygotic twins. Arch Dermatol, 120, 11, (Nov 1984),1418-9, 0003-987X

Piskin, G., Sylva-Steenland, R. M., Bos, J. D., \& Teunissen, M. B. (2006). In vitro and in situ expression of IL-23 by keratinocytes in healthy skin and psoriasis lesions: enhanced expression in psoriatic skin. J Immunol; 176, 3, (Feb 2006), 1908-15, 0022-1767

Piskin, G., Tursen, U., Sylva-Steenland, R. M., Bos, J. D., \& Teunissen, M. B. (2004). Clinical improvement in chronic plaque-type psoriasis lesions after narrow-band UVB therapy is accompanied by a decrease in the expression of IFN-gamma inducers IL-12, IL-18 and IL-23. Exp Dermatol, 13, 12, (Dec 2004), 764-72

Popa, C., Netea, M. G., Radstake, T., Van der Meer, J. W., Stalenhoef, A. F., van Riel, P. L., \& Barerra, P. (2005). Influence of antitumour necrosis factor therapy on cardiovascular risk factors in patients with active rheumatoid arthritis. Ann Rheum Dis, 64, 2, (Feb 2005), 303-305, 0003-4967

Prevoo, M. L., van't Hof, M. A., Kuper, H. H., van Leeuwen, M. A., van de Putte, L. B., \& van Riel, P. L. (1995). Modified disease activity scores the include twenty-eight joint counts: development and validation in a prospective longitudinal study of patients with rheumatoid arthritis. Arthritis Rheum, 38, 1, (Jan 1995), 44-48, 0004-3591

Prinz, J. C. (2001). Psoriasis vulgaris-a sterile antibacterial skin reaction mediated by crossreactive T cells? An immunological view of the pathophysiology of psoriasis. Clin Exp Dermatol, 26, 4, (Jun 2001), 326-32

Prinz, J., Braun-Falco, O., Meurer, M., Daddona, P., Reiter, C., Rieber, P., \& Riethmüller, G. (1991). Chimaeric CD4 monoclonal antibody in treatment of generalised pustular psoriasis. Lancet, 338, 8762, (Aug 1991), 320-1, 0140-6736

Product Monograph. (2008). Stelara (ustekinumab). Janssen-Ortho Inc, Toronto, Ontario. 
Queiro-Silva, R., Torre-Alonso, J. C., Tinture-Eguren, T., \& Lopez-Lagunas, I. (2003). A polyarticular onset predicts erosive and deforming disease in psoriatic arthritis. Ann Rheum Dis, 62, 1, (Jan 2003), 68-70, 0003-4967

Radtke, B., Reich, K., Blome, C., Rustenbach, S., \& Augustin, M. (2009). Prevalence and clinical features of psoriatic arthritis in 2009 patients with psoriasis: results of a German national survey. J Eur Acad Dermatol Venerol 23, 6, (Jun 2009), 683-691

Rapp, S. R., Feldman, S.R., Exum, L., Fleischer, A. B., \& Reboussin, D. M. (1999). Psoriasis causes as much disability as other major medical diseases. J Am Acad Dermatol, 41, 3 Pt 1, (Sep 1999), 401-407

Reddy, M., Davis, C., Wong, J., Marsters, P., Pendley, C., \& Prabhakar, U. (2007). Modulation of CLA, IL-12R, CD40L, and IL-2Ralpha expression and inhibition of IL-12 and IL-23 induced cytokine secretion by CNTO 1275. Cell Immunol, 247, 1, (May 2007), 1-11, 0008-8749

Reveille, J.D., Conant, M. A., \& Duvic, M. (1990). Human immunodeficiency virusassociated psoriasis, psoriatic arthritis, and Reiter's syndrome: a disease continuum?. Arthritis Rheum, 33, 10, (Oct 1990), 1574-8, 0004-3591

Ritchlin, C., Haas-Smith, S. A., Hicks, D., Cappuccio, J., Osterland, C. K., \& Looney, R. J. (1998). Patterns of cytokine production in psoriatic synovium. J Rheumatol, 25, 8, (Aug 1998), 1544-1552, 0315-162X

Rizzo, H. L., Kagami, S., Phillips, K. G., Kurtz, S. E., Jacques, S. L., \& Blauvelt, A. (2011). IL23-mediated psoriasis-like epidermal hyperplasia is dependent on IL-17A. J Immunol, 186, 3, (Feb 2011), 1495-502, 0022-1767

Rogalski, C., Meyer-Hoffert, U., Proksch, E., \& Wiedow, O. (2002). Human leukocyte elastase induces keratinocyte proliferation in vitro and in vivo. J Invest Dermatol, 118, 1, (Jan 2002), 49-54, 0022-202X

Rondinone, C. M. (2006). Adipocyte-derived hormones, cytokines, and mediators. Endocrine, 29, 1, (Feb 2006), 81-90, 0969-711X

Sano, S., Chan, K. S., Carbajal, S., Clifford, J., Peavey, M., Kiguchi, K., Itami, S., Nickoloff, B. J., \& DiGiovanni, J. (2005). Stat3 links activated keratinocytes and immunocytes required for development of psoriasis in a novel transgenic mouse model. Nat Med, 11, 1, (Jan 2005), 43-9, 1078-8956

Saphiro, J., Cohen, A. D., David, M., Hodak, E., Chodik, G., Viner, A., Kremer, E., \& Heymann, A. (2007). The association between psoriasis, diabetes mellitus, and atherosclerosis in Israel: a case-control study. J Am Acad Dermatol, 56, 4, (Apr 2007), 629-634

Scalon, J. V., Exter, B. P., Steinberg, M., \& Jarvis, C. I. (2009). Ustekinumab: treatment of adult moderate to severe chronic plaque psoriasis. Ann Pharmacother 43, 9, (Sep 2009), 1456-1465, 1060-0280

Smith, R. L., Warren, R. B., Griffiths, C. E. M., \& Worthington, J. (2009). Genetic susceptibility to psoriasis: an emerging picture. Genome Med 22, 1, (Jul 2009), 72

Sobell, J. M., Kalb, R. E., \& Weinberg, J. M. (2009). Management of moderate to severe plaque psoriasis (part I): clinical update on T-cell modulators and investigational agents. J Drugs Dermatol, 8, 3, (Mar 2009), 230-238

Song, I. H., Appel, H., Haibel, H., Loddenkemper, C., Braun, J., Sieper, J., \& Rudwaleit, M. (2008). New onset of Crohn's disease during treatment of active ankylosing spondylitis with etanercept. J Rheumatol, 35, 3, (Mar 2008), 532-536, 0315-162X 
Soubrier, M., Jouanel, P., Mathieu, S., Poujol, D., Claus, D., Dubost, J. J., \& Ristori, J. M. (2008). Effects of antitumor necrosis factor therapy on lipid profile in patients with rheumatoid arthritis. Joint Bone Spine, 75, 1, (Jan 2008), 22-24, 1297-319X

Spanakis, E., Sidiropoulos, P., Papadakis, J., Ganotakis, E., Katsikas, G., Karvounaris, S., Bizaki, A., Kritikos, H., \& Boumpas, D. T. (2006). Modest but sustained increase of serum high density lipoprotein cholesterol levels in patients with inflammatory arthritides treated with infliximab. J Rheumatol 33, 12, (Dec 2006), 2440-2446, 0315$162 X$

Steinman, R. M., Hawiger, D., \& Nussenzweig, M. C. (2003). Tolerogenic dendritic cells. Annu Rev Immunol, 21, (Dec 2003), 685-711

Stern, R. S., Nijsten, T., Feldman, S. R., Margolis, D. J., \& Rolstad, T. (2004). Psoriasis is common, carries a substantial burden even when not extensive, and is associated with widespread treatment dissatisfaction. J. Invest Dermatol Symp Proc, G 2, (Mar 2007), 136-139, 1087-0024

Stratis, A., Pasparakis, M., Rupec, R. A., Markur, D., Hartmann, K., Scharffetter-Kochanek, K., Peters, T., van Rooijen, N., Krieg, T., \& Haase, I. (2006). Pathogenic role for skin macrophages in a mouse model of keratinocyte-induced psoriasis-like skin inflammation. J Clin Invest, 116, 8, (Aug 2006), 2094-104, 0021-9738

Strober, B. E., \& Menon, K. (2005). Folate supplementation during methotrexate therapy for patients with psoriasis. J Am Acad Dermatol, 53, 4, (Oct 2005), 652-659

Sugiyama, H., Gyulai, R., Toichi, E., Garaczi, E., Shimada, S., Stevens, S. R., McCormick, T. S., \& Cooper, K. D. (2005). Dysfunctional blood and target tissue CD4+ CD25 high regulatory $\mathrm{T}$ cells in psoriasis: mechanism underlying unrestrained pathogenic effector T cell proliferation. J Immunol, 174, 1, (Jan 2005), 164-73, 0022-1767

Sugiyama, H., McCormick, T. S., Cooper, K. D., \& Korman, N. J. (2008). Alefacept in the treatment of psoriasis. Clin Dermatol, 26, 5, (Sep-Oct 2008), 50-58, 0738-081X

Taler, S. J., Textor, S. C., Canzanello, V. J., \& Schwartz, L. (1999). Cyclosporin-induced hypertension: incidence, pathogenesis and management. Drug Saf, 20, 5, (May 1999), 437-449

Taniguchi, M., Seino, K., \& Nakayama, T. (2003). The NKT cell system: bridging innate and acquired immunity. Nat Immunol, 4, 12, (Dec 2003), 1164-5, 1529-2908

Teunissen, M. B. M. (2005). Langerhans cells and other skin dendritic cells, In: Skin Immune System: Cutaneous Immunology and Clinical Immunodermatology, Bos, J. D., 123-82, Boca Raton CRC Press, 0849319595, FL

Toichi, E., Tachibana, T., \& Furukawa, F. (2000). Rapid improvement of psoriasis vulgaris during drug-induced agranulocytosis. J Am Acad Dermatol, 43, 2, (Aug 2000), 391-5

Toichi, E., Torres, G., McCormick, T. S., Chang, T., Mascelli, M. A., Kauffmann, C. L., Aria, N., Gottlieb, A. B., Everitt, D. E., Frederick, B., Pendley, C. E., \& Cooper, K. D. (2006). An anti-IL-12p40 antibody down-regulates type 1cytokines, chemokines, and IL-12/IL-23 in psoriasis. J Immunol, 177, 7, (Oct 2006), 4917-4926, 0022-1767

Torres, M. I., \& Rios, A. (2008). Current view of the immunopathogenesis in inflammatory bowel disease and its implications for therapy. World J Gastroenterol, 14, 13, (Apr 2008), 1972-1980, 1007-9327

Torti, D. C., \& Feldman, S. R. (2007). Interleukin-12, interleukin-23, and psoriasis: current prospects. J Am Acad Dermatol, 57, 6, (Dec 2007), 1059-1068

van den Brande, J., Braat, H., van den Brink, G. R., Versteeg, H. H., Bauer, C. A., Hoedemaeker, I., van Montfrans, C., Hommes, D. W., Peppelenbosch, M. P., \& van 
Deventer, S. J. (2003). Infliximab but not etanercept induces apoptosis in lamina propria T-lymphocytes from patients with Crohn's disease. Gastroenterology, 124, 7, (Jun 2003), 1774-1785, 0016-5085

van den Oord, J. J., \& de Wolf-Peeters, C. (1994). Epithelium-lining macrophages in psoriasis. Br J Dermatol, 130, 5, (May 1994), 589-94, 0007-0963

van der Heijde, D., Kavanaugh, A., Gladmann, D. D., Antoni, C., Krueger, G. G., Guzzo, C., Zhou, B., Dooley, L. T., de Vlam, K., Geusens, P., Birbara, C., Halter, D., \& Beutler, A. (2007). Infliximab inhibits progression of radiographic damage in patients with active psoriatic arthritis through one year of treatment: results from the induction and maintenance psoriatic arthritis clinical trial 2. Arthritis Rheum, 56, 8, (Aug 2007), 2698-2707, 0004-3591

van der Vliet, H. J., von Blomberg, B. M., Nishi, N., Reijm, M., Voskuyl, A. E., van Bodegraven, A. A., Polman, C. H., Rustemeyer, T., Lips, P., van den Eertwegh, A. J., Giaccone, G., Scheper, R. J., \& Pinedo, H. M. (2001). Circulating V(alpha24+) Vbeta11+ NKTcell numbers are decreased in a wide variety of diseases that are characterized by autoreactive tissue damage. Clin Immunol, 100, 2, (Aug 2001), $144-$ $148,1521-6616$

van Lingen, R. G., Ko“rver, J. E., van de Kerkhof, P. C., Berends, M. A., van Rens, D. W., Langewouters, A. M., Boezeman, J. B., Seyger, M. M., \& de Jong, E. M. (2008). Relevance of compartmentalization of T-cell subsets for clinical improvement in psoriasis: effect of immune-targeted antipsoriatic therapies. Br J Dermatol, 159, 1, (Jul 2008), 91-96, 0007-0963

Vissers, W. H., Arndtz, C. H., Muys, L., Van Erp, P. E., de Jong, E. M., \& van de Kerkhof, P. C. (2004a). Memory effector (CD45RO+) and cytotoxic (CD8+) T cells appear early in the margin zone of spreading psoriatic lesions in contrast to cells expressing natural killer receptors, which appear late. Br J Dermatol, 150, 5, (May 2004), 852859, 0007-0963

Vissers, W. H., Berends, M., Muys, L., van Erp, P. E., de Jong, E. M., \& van de Kerkhof, P. C. (2004b). The effect of the combination of calcipotriol and betamethasone dipropionate versus both monotherapies on epidermal proliferation, keratinization and T-cell subsets in chronic plaque psoriasis. Exp Dermatol, 13, 2, (Feb 2004), 106112

Vissers, W. H., van Vlijmen, I., van Erp, P. E., de Jong, E. M., \& van de Kerkhof, P. C. (2008). Topical treatment of mild to moderate plaque psoriasis with $0.3 \%$ tacrolimus gel and $0.5 \%$ tacrolimus cream: the effect on SUM score, epidermal proliferation, keratinization, T-cell subsets and HLA-DR expression. Br J Dermatol, 158, 4, (Apr 2008), 705-712, 0007-0963

Wang, H., Peters, T., Sindrilaru, A., \& Scharffetter-Kochanek, K. (2009). Key role of macrophages in the pathogenesis of CD18 hypomorphic murine model of psoriasis. J Invest Dermatol, 129, 5, (May 2009), 1100-14, 0022-202X

Willment, J.A., Lin, H. H., Reid, D. M., Taylor, P. R., Williams, D. L., Wong, S. Y., Gordon, S., \& Brown, G. D. (2003). Dectin-1 expression and function are enhanced on alternatively activated and GM-CSF-treated macrophages and are negatively regulated by IL-10, dexamethasone, and lipopolysaccharide. J Immunol, 171, 9, (Nov 2003), 4569-73, 0022-1767 
Wittig, B. M. (2007). Drug evaluation: CNTO 1275, a mAb against IL-12/ IL-23p40 for the potential treatment of inflammatory diseases. Curr Opin Investig Drugs, 8, 11, (Nov 2007), 947-954, 1472-4472

Wu, J. J., \& Tsai, T. F. (2008). Recurrent hyperglycemia during adalimumab treatment in a patient with psoriasis. Arch Dermatol, 144, 10, (Oct 2008), 1403-1404, 0003-987X

$\mathrm{Xu}, \mathrm{Z} ., \mathrm{Vu}, \mathrm{P} ., \mathrm{Lee}, \mathrm{H} ., \mathrm{Hu}, \mathrm{C} .$, Ling, J., Yan, H., Baker, D., Beutler, A., Pendley, C., Wagner, C., Davis, H. M., \& Zhou, H. (2009). Population pharmacokinetics of golimumab an anti-tumor necrosis factor-a human monoclonal antibody, in patients with psoriatic arthritis. J Clin Pharmacol 49, 9, (Sep 2009), 1056-1070, 0091-2700

Yazdani-Biuki, B., Stelzl, H., Brezinschek, H. P., Hermann, J., Mueller, T., Krippl, P., Graninger, W., \& Wascher, T. C. (2004). Improvement of insulin sensitivity in insulin resistant subjects during prolonged treatment with the anti-TNF-alpha antibody infliximab. Eur J Clin Invest, 34, 9, (Sep 2004), 641-642, 0014-2972

Zachariae, H., Zachariae, R., Blomqvist, K., Davidsson, S., Molin, L., Mørk, C., \& Sigurgeirsson, B. (2002). Quality of life and prevalence of arthritis reported by 5,795 members of the Nordic Psoriasis Associations. Data from the Nordic Quality of Life Study. Acta Derm Venereol, 82, 2, (2002), 108-113, 0001-5555

Zenz, R., Eferl, R., Kenner, L., Florin, L., Hummerich, L., Mehic, D., Scheuch, H., Angel, P., Tschachler, E., \& Wagner, E. F. (2005). Psoriasis-like skin disease and arthritis caused by inducible epidermal deletion of Jun proteins. Nature, 437, 7057, (Sept 2005), 369-75, 0028-0836

Zhao, Y., Fishelevich, R., Petrali, J. P., Zheng, L., Anatolievna, M. A., Deng, A., Eckert, R. L., \& Gaspari, A. A. (2008). Activation of keratinocyte protein kinase C zeta in psoriasis plaques. J Invest Dermatol, 128, 9 (Sept 2008), 2190-2197, 0022-202X

Zheng, Y., Danilenko, D. M., Valdez, P., Kasman, I., Eastham-Anderson, J., Wu, J., \& Ouyang, W. (2007). Interleukin-22, a T(H)17 cytokine,mediates IL-23-induced dermal inflammation and acanthosis. Nature, 445, 7128, (Feb 2008), 648-51, 00280836

Zhou, X., Krueger, J. G., Kao, M. C., Lee, E., Du, F., Menter, A., Wong, W. H., \& Bowcock, A. M. (2003). Novel mechanism of T-cell and dendritic cell activation revealed by profiling of psoriasis on the 63,100-element oligonucleotide array. Physiol Genomics, 13, 1, (Mar 2003), 69-78, 1094-8341 


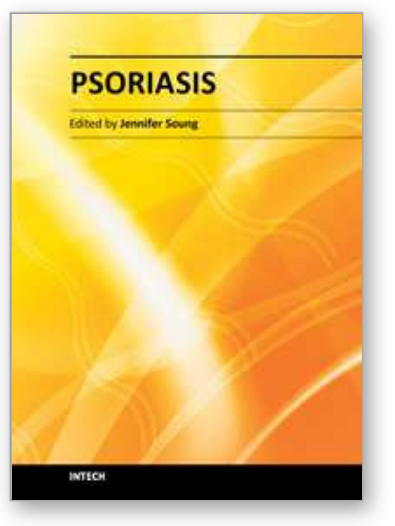

\author{
Psoriasis \\ Edited by Dr. Jennifer Soung
}

ISBN 978-953-307-878-6

Hard cover, 372 pages

Publisher InTech

Published online 15, February, 2012

Published in print edition February, 2012

We hope you enjoy and find the information provided in this book useful in your research or practice. We urge that you continue to keep abreast of the new developments in psoriasis and share your knowledge so that we may advance treatment and cures of psoriasis.

\title{
How to reference
}

In order to correctly reference this scholarly work, feel free to copy and paste the following:

Amedeo Amedei and Mario Milco D'Elios (2012). The Role of Immune Response and the Impact of Biological Drugs in Psoriasis Patients, Psoriasis, Dr. Jennifer Soung (Ed.), ISBN: 978-953-307-878-6, InTech, Available from: http://www.intechopen.com/books/psoriasis/the-role-of-immune-response-and-the-impact-of-biologicaldrugs-in-psoriasis-patients

\section{INTECH}

open science | open minds

\section{InTech Europe}

University Campus STeP Ri

Slavka Krautzeka 83/A

51000 Rijeka, Croatia

Phone: +385 (51) 770447

Fax: +385 (51) 686166

www.intechopen.com

\section{InTech China}

Unit 405, Office Block, Hotel Equatorial Shanghai

No.65, Yan An Road (West), Shanghai, 200040, China 中国上海市延安西路65号上海国际贵都大饭店办公楼 405 单元

Phone: +86-21-62489820

Fax: $+86-21-62489821$ 
(C) 2012 The Author(s). Licensee IntechOpen. This is an open access article distributed under the terms of the Creative Commons Attribution 3.0 License, which permits unrestricted use, distribution, and reproduction in any medium, provided the original work is properly cited. 